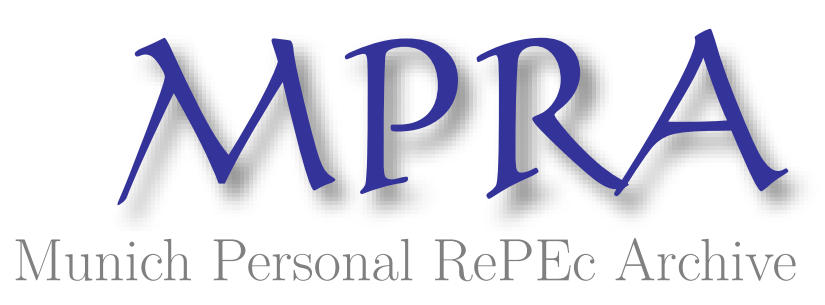

\title{
How Global Warming Can Affect Where People Live? Evidence from Flood Surprises
}

Petkov, Ivan

Northeastern University

26 March 2018

Online at https://mpra.ub.uni-muenchen.de/85759/

MPRA Paper No. 85759, posted 11 Apr 2018 05:44 UTC 


\title{
How Global Warming Can Affect Where People Live? Evidence from Flood Surprises
}

\author{
Ivan Petkov *
}

March 26, 2018

\begin{abstract}
This paper challenges the notion that changes in flood risk will have a minimal impact on population because of the availability of insurance and that most of the effect, if any, will be borne out by the real estate market. Insurance premiums even when subsidized are a cost that a household will need to pay with the increase in flood risk. The evidence suggests that flood events, historical and contemporaneous, play a role in the determination of the local perceived flood risk. Attractive communities that have positive growth before the flood surprise are hardest hit. They see a persistent $1.4 \%$ dip in population with a $0.7 \%$ decrease in the pre-flood trend. Flooding does not affect population in the rest of the high surprise locations. Instead, they see close to $4 \%$ drop real estate values with the biggest effect among higher tier housing. There is also evidence that flood incidence in these communities is higher among the low-income population as suggested by relief payments by FEMA.
\end{abstract}

JEL Classification: R11, R30, J61, Q54

Keywords: Population, Flood Surprises, Climate Change

Real Estate, Natural Disasters

${ }^{*}$ Author's affiliation: Northeastern University; email: i.petkov@neu.edu; tel:857-869-5353. Present address: Department of Economics, Northeastern University, 360 Huntington Ave, Boston, MA 02115; 


\section{Introduction}

Extreme weather and the resulting damage is a frequent concern for a big fraction of the US population. Flooding is one of the most destructive consequences since water damage is hard to reverse when it comes to building structures and equipment. This is why the US Federal Government has instituted and maintains a highly subsidized flood insurance program. The availability of insurance implies that households in flood-prone areas can minimize their flood risk exposure. The fact that premiums are subsidized and do not re-price after flooding suggests that a bigger portion of the population can afford to live in relatively risky locations compared to a system with premiums more closely tied to risk. Consequently, changes in climate which bring more extreme weather and create the potential for flooding in unexpected places will leave population patterns unaltered - historically flood-prone places already minimize risk through insurance while newly flooded places will start utilizing insurance as flood risk increases. Real estate prices can decline to reflect the additional cost of insurance as more risk-tolerant households replace less risk-tolerant ones but the total population is not expected to fundamentally change as locations become more prone to flooding unless local productivity is affected.

This paper challenges the notion that changes in flood risk will have a minimal impact on population because of the availability of insurance and that most of the effect, if any, will be borne out by the real estate market. Insurance premiums even when subsidized are a cost that a household will need to pay with the increase in flood risk. Additionally, there are other costs such as foregone wages and temporary relocation expenses which are not insurable. An upward revision in flood risk can therefore make a location less attractive compared to other places with similar characteristics but unchanged flood risk. While people already in places where risk increases usually leave after selling at a discount, keeping population unchanged, new movers who choose among a set of destinations will likely steer away. Increases in the flood probability can, therefore, not only affect real estate values but also total population, especially in places that were an attractive destination prior to the risk revision. 
I evaluate the effect of upward revisions of flood risk on population and real estate prices. To identify flooding and flood surprises I compile a new comprehensive dataset that includes insured and uninsured damage at the level of the community between 2003 and 2013. Insured damage is based on records by the National Flood Insurance Program (NFIP) while uninsured damage is based on information from the Federal Emergency Management Agency (FEMA) and the Small Business Administration (SBA). The compiled flood information measures damage consistently and allows for comparison across locations and over time. Revisions of flood risk are likely to occur in communities with low flood history which do experience a flood event. I use information from NFIP on total losses between 1978 and 2000 to identify locations with flood surprises and examine the effect of likely risk revision on total population and real estate values. I further explore the role of new movers by separating locations with risk revisions based on their pre-event growth. Finally, I examine the regional heterogeneity of the national results.

The evidence suggests that flood events, historical and contemporaneous, play a role in the determination of the local perceived flood risk. The average insurance payouts are almost double at locations with history of flood losses. With risk already high enough in these places insurance purchase is likely common. Floods in communities with low historical losses generate smaller payouts which suggests that they were not widely expected and constitute flood surprises. I find a big distinction in the impact of floods in the latter communities, a result consistent with increases in perceived risk. Population declines by $0.3 \%$ relative to a fixed effect and a linear trend during the year following the event. The effect persists in the period after the impact year with an average decline close to $0.5 \%$. There is also evidence of a break in the pre-flood trend. Locations with low surprise events do not experience any population changes. Attractive communities that have positive growth before the flood surprise are hardest hit. They see a persistent $1.4 \%$ dip in population with a $0.7 \%$ decrease in the pre-flood trend. Flooding does not affect population in the rest of the high surprise locations. Instead, they see close to a $4 \%$ drop real estate values with the biggest effect 
among higher tier housing. There is also evidence that flood incidence in these communities is higher among the low-income population as suggested by relief payments by FEMA. Housing values are not affected in the attractive communities which suggests that they do not price the increased flood risk and effectively become more expensive. This is possibly driven by previous strong demand for new housing and expectations that flood impact is transitory. Regional evidence strongly suggests that the population decline in attractive communities after a flood surprise is a general phenomenon across the nation. The events considered do not significantly impact the housing supply - the median damage as a fraction of total real estate value is $0.05 \%$, the $75^{\text {th }}$ percentile is $0.14 \%$, and the $95^{\text {th }}$ percentile is $0.87 \%$. The relative small size implies that observed effects are due to revisions in risk expectations.

The results in this paper help us understand how flooding, the most significant source of impact from natural disasters, affects where people live and how its risk is reflected in house values. They allow us to interpret the effect of possible climate change across the country and how many people will remain in relatively risky locations over time. Expectations about flood risk are critical and more important than overall level of damage. As a result population and real estate effects only emerge after flood surprises - in the rest of the cases flood events appear to already be incorporated in these variables and only generate insurance payouts. This is an interesting result given the wide availability of flood insurance which can minimize the upward revision of risk after flood surprises. It further implies that natural disasters are not necessarily exogenous events in all locations, only the actual timing is. The evidence in the paper also emphasizes that a general economic analysis of the impact of natural disasters has to account for changes in perceived risk. The response of the local economy at a low surprise location may not be comparable to that of a high surprise one because of the different population and real estate trajectories. The results also emphasize that the attractiveness of the community determines how it is ultimately impacted by surprises: strong demand for new housing means that population is mostly affected; weaker demand implies that house prices are mostly affected. 
This paper can be placed within several different literatures. First, it is related to the broad literature on location choice and the spatial labor market equilibrium (Moretti (2011), Gleaser and Gyourko (2005), Gleaser and Gottlieb (2009), Diamond (2014)). This paper is close in spirit to Topel (1986) who also emphasizes the importance of expectations in the location choice. This literature generally investigates the effect of Bartik-style productivity shocks across local markets on migration, real estate prices, and wages. The shock I study affects expectations about the future cost of living but has a minimal effect on local productivity since most of the damage is relatively small. Second, the paper is related to the literature on natural disasters. This literature mostly focuses on the effect of hurricanes at different geographical levels and measures damage in a variety of ways. The current study also includes hurricanes since they produce significant flood damage. Strobl (2011) uses wind speed as a proxy for damage and finds that hurricanes lower county GDP by $0.5 \%$ and do not change total population but affect its composition. Deryugina (2017) uses hurricane paths and simulation estimates of damage to examine the disaster and non-disaster transfers to affected communities as well as the effect on demographic and economic variables. She finds that population is not affected. Both papers utilize county-level data based on estimates of damage based on hurricane locations. I use community-level losses that are consistently imputed by federal agencies and do not rely on associations between wind speed/hurricane path and damage. Importantly, I focus on communities where flood events constitute surprises and lead to changes in perceived risk since this is where the biggest impact is likely to occur. Third, this paper is related to the literature on expectation formation and learning after rare events. It is close to Gallagher (2014) which examines the change in insurance take up after flood events. The paper concludes that flood events lead to revisions of perceived risk which lead to higher insurance purchase that is not very persistent. The evidence is complementary to my findings since it suggests that living in flooded communities becomes more expensive.

The rest of the paper is structured as follows. Section 2 discusses the institutional details 
of the flood insurance program and describes how the flood data was compiled. Section 3 presents the main results. Section 4 examines the regional heterogeneity of the main results. Section 5 concludes the paper.

\section{Flooding Dataset and Institutional Details}

Flood insurance in the US is administered by the federal government through the National Flood Insurance Program (NFIP). The program makes insurance available at communities that maintain a flood zone map and enforce local building code. The map delineates Special Flood Hazard Areas (SFHA) with varying degrees of flood risk. Two general SFHAs are the 100-year and 500-year flood zones where flood is expected to occur with certainty every 100/500 years respectively. The risk within the 500-year SFHA is not uniform - areas close to the 100-year zone will have a higher risk of flooding if the geography is similar. Insurance purchase is mandatory for structures within the 100-year zone but not required elsewhere. This is important because risk expectations rather than local regulation will determine the insurance purchase outside of the 100-year zone.

NFIP maintains an official record of the number of policies sold, total coverage, and total payouts at the level of a given community since the program effectively partners with the local authority enforcing the flood map and building code. The geographical level is consistent with the US Census definition of general-purpose government units such as cities, towns, townships, as well as the remaining county areas (county balance). Insurance information includes homeowners and business structures. NFIP does not list payouts associated with particular flood events. Instead, it shows up-to-date payouts starting from 1978. I use historical observations of the official record taken approximately twice a year between 2003 and 2014 to calculate the amount of new payouts claimed at each community. These represent insured damages associated with flood events during each year. I carefully link the observed payouts to the set of FEMA disaster declarations for each state. The matching was not 
automated but involved reading the description of FEMA declarations for each state/year and associating flood events in the covered counties to observed insurance payouts at communities in those counties. This link allows me to identify both the amount of insured and uninsured damages for each FEMA event. The uninsured damages are sourced from FEMA's individual/public assistance data and from Small Business Administration?s (SBA) individual/business lending data. A disaster declaration makes federal funding available to affected individuals without insurance. They can receive either a direct non-refundable payment or a highly subsidized loan depending on their ability to take on additional credit. Jaffe (2015) suggests that FEMA requests detailed financial information with the application for relief which is used to determine whether the applicant is contacted directly by FEMA or by SBA. FEMA administers the direct payments and SBA extends the loans. Both maintain a registry that identifies the amount of assistance provided and the related total damage at the zip-code level for each disaster declaration. Altogether, total damage in the data has four components: insured individual+business from NFIP; uninsured individual from FEMA and SBA; uninsured business from SBA; uninsured public from FEMA. In this paper I focus primarily on total damage. The components are only used to control for events where most of the damage comes from one of the source.

Population information comes from the annual US Census estimates for cities and towns. The geographical detail of this data maps directly into the community level of the flood damage data. Locations with less than fifteen thousand people are combined with the county balance areas to make sure that results are not driven by very small settlements. Real estate information comes from the Zillow service and is available at the zip-code level. It provides estimates of house values separated into three tiers. These are calculated by splitting the price distribution of all housing into three parts and reporting the middle point of each. The rest of the information used in this paper comes from the 2000 US Census data at the block-group level.

The paper identifies floods according to the relative size of the damages. Cases where 
more than $0.01 \%$ of the total real estate value of the community is destroyed constitute a flood event while the rest are censored. I focus on a wide spectrum of events because relative damage is context specific - less destructive floods can have significant impact on perceived risk if they occur in areas with no flood history.

The first panel of Figure 1 shows a map of all communities that flooded between 2003 and 2013. Flooding appears to be widespread across the country and not only a coastal phenomenon. In the interior major floods result from significant rain or snowmelt which causes rivers and creeks to spill in the surrounding areas. Some of the communities in the sample experience repeated disasters during the sample period. I will separate these into a different category since their event study explicitly includes an interim period. Furthermore, the fact that these places flood so frequently suggests that they are fundamentally different from the rest of the cases. The second panel of Figure 1 shows single and multiple flood locations. There are about three times more single than multiple hit places (1,519 vs 542). A significant portion of the latter are located by the coast while the former are more uniformly distributed.

Table 1 lists some summary statistics for the flood data. The information is categorized by the number of floods since this allows us to focus on the two major groups in the analysis: places with no floods and places with one flood. The latter also included places with two back-to-back floods across two years. There are 1,771 communities without any flooding and 1,519 with one flood. Median population at each group is approximately 34/31 thousand, respectively; median growth rate is $0.55 \% / 0.39 \%$ respectively. Relative damage varies from $0.02 \%$ at the $25^{\text {th }}$ percentile to $0.87 \%$ at the $95^{\text {th }} / 3.23 \%$ at the $99^{\text {th }}$ percentile. In dollar values these are $\$ 0.64$ million (25 $5^{\text {th }}$ percentile), $\$ 42.39$ million (95 ${ }^{\text {th }}$ percentile), and $\$ 289$ million $\left(99^{\text {th }}\right.$ percentile). The distribution within each state shows that there are sufficient number of locations without any flooding.

I identify flood surprises by utilizing the total number of structures completely destroyed due to flooding between 1978 and 2003. This information is available from the NFIP data for 
each community and captures the its flood history. I further normalize this number by the total building structures and compare to the state median across all location that experience a flood. Communities below the median are considered low-risk and flood event is assumed to generate a higher surprise than the rest. This ensures that there are sufficient number of places which can be placed within each category and that the distinction between high and low surprise is region specific.

The second panel of Figure 2 separates the high/low surprise locations. These tend to be contiguous suggesting that flood surprises occur when a flood extends beyond a high-risk area and into a low-risk one. High-risk areas also tend to be contiguous to multiple-flood areas which reinforces the assumption that the former are at a generally higher risk of disaster. The map also confirms that high/low surprise locations are relatively close and are part of the same economic area.

\section{Main Results}

One of the main results in the paper is that the extent to which disaster damages affect a community is determined by its historical experience. Flooding at communities with low flood history constitutes a surprise which increases expected future risk and raises the cost of living in such places. To set the stage for the formal results, consider the experience of three communities in Connecticut: Milford, Bridgeport, and New Haven. All were affected by hurricane Irene in 2011 and Sandy in 2012. Since the events were consecutive they fall in the single-flood group with no interim period. Milford made it into the local news for the extent of losses and the fact that no one had the intention to move. It suffered $\$ 90$ mil in damages ( $0.5 \%$ of real estate value) while Bridgeport and New Haven suffered $\$ 16$ mil $(0.12 \%) / \$ 7$ mil $(0.05 \%)$. The difference in damages implies that Milford should be affected significantly more but its flood history suggests that the event was not such a surprise. Between 1978 and 2003 Milford lost $6.2 \%$ of its structures due to flooding while Bridgeport and New Haven lost 
$0.7 \% / 0.5 \%$ respectively. Figure 3 shows the population growth for each of the communities. We see that the population in Milford was not affected. At the same time the communities with smaller overall damage but with relatively low history of floods experienced population declines. Notice that the communities did not experience a large-scale disaster since damages were relatively small. Nevertheless, they seem to have changed the expectations about future flood risk and the attractiveness of the communities with low history.

\section{Flood Surprise and Insurance Payouts}

The first set of formal results examine the extent to which historical flood losses can be used to identify flood surprises. Regulations require that structures within the 100-year flood zone carry insurance if they have a federally-backed mortgage. Insurance purchase for any other structures will depend to some extent on the perceived risk of a flood. High flood history increases perceived risk and leads to insurance purchase. I examine this relation by comparing the average insurance payouts across the high/low flood history groups in the cross-section of all events. In particular, I test whether a given amount of total damage (insured and uninsured) generates more insurance payouts in locations with historical exposure to flood events i.e. low-surprise communities. I estimate:

$$
\ln \left(\text { Payouts }_{i}=\alpha_{t}+\beta H i t_{i}^{S F} \times \text { Dam }_{i}+\gamma H i t_{i}^{S F} \times \text { Dam }_{i} \times \text { LSurprise }_{i}+\{M F l\}+\epsilon_{i}\right.
$$

where Payouts is total insurance payouts per capita after an event at community $i$ and $\alpha_{t}$ is an year effect. $\mathrm{Hit}_{i}^{S F}$ is an indicator for a flood at a single-flood location $i, D_{a} m_{i}$ is total damage per capita (insured+uninsured), and LSurprise L $_{i}$ is an indicator for low surprise

flooding (high flood history). $\{M F l\}$ abbreviates the same set of indicators for locations with multiple floods. Positive $\gamma$ implies that higher overall damage leads to more insurance payouts at places with high history of flooding relative to places with low history. I estimate two variants of the model above: with and without controlling for total damage. In the latter case $\gamma$ represents how much more insurance payouts are generated during an average 
flood event at a communities with history of flooding. It is possible that an average flood event in these communities is much more destructive so I also estimate the model holding total damage constant.

Table 2 shows the estimation results. Communities with a low-surprise flood i.e. high flood history have a significantly higher insurance payouts per capita during an average flood event. These locations receive almost double the insurance compensation after an event compared to locations with low previous experience with flooding. Column 2 of Table 2 looks at the regional heterogeneity of this result. I find that high history is associated with higher insurance payout across the US regions. Notice that the Mid-Atlantic and South Atlantic region have higher than national average payouts but even there low surprise communities receive higher amounts. It is possible that low surprise events generate more insurance payouts because they experience more damaging events. Column (3) accommodates this by controlling for overall damage. $1 \%$ increase in total damage leads to $0.43 \%$ increase in insurance payouts at communities with low history of flooding and $0.66 \%$ increase in payouts at high flood history locations. Communities with previous floods 50\% more of the damage through insurance compared to the rest. Column (4) shows that this result is consistent across regions of the US. Interestingly, the Mid-Atlantic area covers a bigger proportion of the overall damages with insurance but history of flooding still drives higher payouts.

Overall, the results provide evidence that flood surprises are related to flood history. They also suggest that high damages in general do not necessarily lead to high impact on the local economy, outside rebuilding activities, because those may be in line with expectations and do not change the perceived risk.

\section{Population Responses}

Next I examine how the population of communities is affected by flood events focusing on surprises and the level of attractiveness prior to the event. I estimate the following model in 
several variations:

$$
\ln \text { Pop }_{i t}=\alpha_{i}+t_{i}+\gamma_{s t}+\beta_{1} H i t_{i t-1}^{S F}+\beta_{2} \text { PostHit }_{i t-2}^{S F}+\beta_{3} \text { PostTrend }_{i t-2}^{S F}+\delta X_{i t-1}+\left\{M F l_{i t-1}\right\}+\epsilon_{i t}
$$

Log population for community $i$ within state $s$ in year $t$ is explained by an individual average, $\alpha_{i}$, individual linear trend, $t_{i}$, and a state-year effect, $\gamma_{s t}$. This specification is flexible enough to allow for time-invariant difference in settlement size and community-specific difference in the population trajectory. The former is important given the heterogeneity in community size in the data. The latter accounts for differences in productivity, amenities, and prior flood events which give rise to different population changes across locations. The state-year effect captures variations in local population which can be traced to the state/national level. The Great Recession is an important factor in the sample which has affected population and can be accommodated with the state-year controls.

I identify the effect of floods by first separating communities according to the number of floods. For the case of the single-flood group (SF) I include an indicator for the year after the flood, $H i t_{i t-1}^{S F}$, an indicator for the period from the second year onwards, Post it $_{i t-2}^{S F}$, and a trend break after the flood, PostTrend $d_{i t-2}^{S F}$. For the case of more than one floods I additionally include an indicator for the period(s) between the floods. The results in this paper focus on the single-hit communities since they represent the bulk of the location count and the identification is more straightforward. The $\beta_{1}$ represents the contemporaneous effect of the flood i.e. within the first year; $\beta_{2}$ captures the persistence of the initial effect; $\beta_{3}$ allows for a change in the trend relative to the pre-flood one. $X_{i t-1}$ includes a set of additional important indicators that have been interacted with $H_{i t-1}^{S F}$, PostHit $t_{i t-2}^{S F}$, and PostTrend PI-2 $_{\text {. }}^{S F}$ These include indicators for: top 66th percentile of FEMA/NFIP/SBA business/SBA homeowners damage shares; bottom 33th percentile of relative damages; top 50 th percentile of share of non-construction occupations; top 50th percentile of share of renters. The last two indicators are based on the 2000 Census values and therefore are time-invariant. While the fixed effects already control for these differences I can still identify 
whether locations with more non-construction workers and more renters respond differently to flood events. The first controls for the diversity in the local job opportunities and the second controls for capacity to accommodate the displaced from floods. Both can lead to increases in local population even if the community is hit by a flood. Additionally, flood events lead to an inflow of emergency/construction/temporary workers. These will likely be housed in communities with higher capacity of rentals. This is the reason why I control for the rental share. This control will not be sufficient if these additional workers are placed in temporary housing. In this case it is important to examine the persistence of the estimated flood impact since temporary workers will lead to a reversal of the initial impact as they leave. Higher PostHit estimate is consistent with outflow of temporary workers.

The baseline results assume that the level of flood surprise does not affect the responses. I examine whether these differ by the level of surprise. Finally, I separate the impact by pre-flood population growth (last five years). Most communities have turnover in local population. Growing locations attract more new comers and experience demand for new housing because of improved labor market or/and local amenities. Conditioning on pregrowth can reveal how persistent demand for housing affects the overall response to a flood surprise. It also helps us interpret the trend break by identifying whether growing or stagnant locations see a change in trajectory. Note that pre-growth is time varying while the controls for the local economy/renters are not. The former accounts for higher-frequency shocks while the latter identifies lower-frequency ones such as whether the location is a bigger city. For example, places with diversified local economies are not expected to necessarily be growing. For that to happen they need additionally to be affected by a productivity shock. Although both factors are important I focus on the effect of the higher-frequency shock and simply control for the other one.

Table 3 shows the results from the population model. Each of the three versions of the baseline model includes estimates without/with $X_{i t-1}$ controls. Population at the average location with flood from model (1) is not impacted by the event. The average location from 
model (2) with less diversified economy and lower availability of rentals among other controls sees a $0.92 \%$ decline in population in the year following the event. This decline is persistent and is accompanied by a decline in the pre-flood trajectory of $0.4 \%$. The difference in results comes from the fact that the composition of the local economy, the availability of rentals, and the share of FEMA-recoded damages each soften the flood impact or in some cases increase population. While these are important results on their own the paper focuses on the impact of flood surprises and persistent demand for new housing so they are designated to the set of controls. Overall, model (2) shows that flooded places with lower rental share, higher construction occupations share, and intermediate damage shares see a decrease in expected population which is persistent and accompanied by a trend break. Even without accounting for the level of surprise population is negatively impacted.

The effect of flood surprises is identified in model (3) and (4). In both cases they lead to significant declines in population on impact and in the following periods. An average location from (3) is only affected when the flood is unexpected. On impact expected population drop by $0.3 \%$; the effect is persistent; pre-flood trend declines by $0.15 \%$ after the event. Compared to (1) where floods do not affect population we see that identifying surprises is critical. This is consistent with the insurance results and suggests that revisions of flood risk disrupt the pre-flood population dynamic. In the case with controls flood surprises generate significantly bigger declines in population: $1.2 \%$ decline on impact, $1 \%$ in the post period, and $0.6 \%$ decline in pre trend. Low surprise floods also affect population. Interestingly, the regional results show that this effect is not a nation-wide phenomenon but comes from the northeastern region. Both estimates (3) and (4) strongly suggest that expected population declines when a flood occurrence breaks with historical experience. While the initial decline in population is persistent it is still relatively small at $1 \%$. The trend break represents a much bigger impact on the population of a community following the event. A $0.6 \%$ decline in the pre-trend amounts to a $3 \% / 6 \%$ lower population in 5/10 years relative to where population is expected to be without the flood. The fact that most events have relatively small magnitude 
implies that the effect stems from revisions of risk expectations. Consequently, biggest population changes will not necessarily overlap with biggest damages. Flooding seems to lead to some population increases in places with more diversified local economies and more rental capacity. This offsets the negative effect from the increase in riskiness. In the cases of flood surprises the second effect is much stronger and leads to overall decrease in population.

The evidence so far shows that surprises disrupt the pre-existing population trajectory. A decline in the linear trend implies a slow down in expansion and stabilizing of population in a growing location; in a stable or declining place it implies loss of population or an acceleration of such loss. To help interpret the trend break I separate the impact effects according to pre-flood growth: positive and negative growth in the preceding five years. This also helps understand how a productivity/amenity shock interacts with risk revisions. The results in (5) and (6) show that the surprise driven population decline occurs primarily in attractive communities with higher pre-flood growth. Population drops by $0.55 \% / 1.4 \%$ without/with controls and remains lower in the post period. There is a decline in the pre trend of $0.4 \% / 0.8 \%$. These communities effectively stop expanding after the flood surprise and population becomes fixed at its pre-flood level. Locations with declining population are either not affected (with controls) or see an increase (without controls). The difference in outcomes by pre-growth after the surprise strongly suggests that the population decline works through the demand for new housing or excess of newcomers. This is consistent with a decrease in the attractiveness of the community following a revision of expected flood risk. Importantly, it requires that the real estate market does not fully compensate the risk increase with a discount that offsets the cost of insurance. Similarly, the fact that lower growth communities are not affected suggests that the real estate there may be discounted providing compensation for higher risk.

It is important to point out an issue that relates to the possible endogeneity of flooding and local economic factors such as high poverty. It is possible that poor communities invest less in flood protection and ultimately experience bigger damages. Here it really matters how 
poverty or a local economic factor is related to the population trajectory before the flood and after the flood. If either of these cause population to be decreasing before the flood then I incorporate this in the model by allowing the trajectory to be different before the flood. For an impact to be significant in this case we have to see that population declines even more than suggested by pre-flood rates driven by poverty or an economic factor. If these factors cause population to respond differently only after the flood i.e. a poor place grows just as rich place before the flood then it is hard for me to disentangle the effect. I can only do it by allowing poor places to respond in a different way after the shock. I accommodate this possibility with a set of controls described above.

\section{Real Estate Responses}

I examine how the housing market responds to surprises and more specifically whether there is evidence of compensating effects by estimating the most restricted version of the model as in (6) above. Results are listed in Table 4 for each of the three tiers provided by Zillow.

There is no evidence that housing values compensate for the increase in flood risk at locations with high pre growth. This is the case for all three tiers of housing. This is consistent with the decrease in population following the event in that potential movers into the location see an increased cost associated with the destination - both the insurance premium and uninsurable damage. The persistent demand for new housing before the event or the expectation that the event is transitory seem to prevent house prices from adjusting. Interestingly, housing in low growth communities declines after a surprise. Top and middletier housing decrease by $2.3 \%-3.4 \%$ on impact; the dip is persistent and remains at close to $4.4 \%$ in the post period. Bottom-tier housing does not appear to decrease on impact although there is evidence of a decline in the post period. The change in real estate prices paired with the lack of population declines suggests that locations without demand for additional housing provide a discount that can compensate for the increase in expected flood risk and the associated costs. This result is consistent with the literature that looks at how health risks 
are priced into real estate values (Davis (2004)). All together the housing and population results suggest the following interpretation. Flood surprises drive upward revisions of the underlying probability of a future flood which in turn raises the cost of living. In locations where demand for housing is low existing structures are sold at a discount that covers the additional cost. This appears to be sufficient to maintain the existing population trajectory. In location where demand for housing is high structures are not sold at a discount, possibly due to expectations that the pre-growth will be maintained, which drives new movers to other destinations.

\section{Low wealth incidence}

The decline in house prices is consistent with turnover in the community whereby higherrisk tolerant households replace less-risk tolerant ones after a reduction in prices. This leaves population unchanged but alters the type of people remaining. This is an example of sorting based on changes in perceived risk. It relies on the assumption that households can finance their exit from the community by trading their house for a comparable structure somewhere else. If this is not the case sorting will not take place as people are prevented from leaving. This is an example of a lock-in effect (Stein (1995)).

I examine the extent to which low wealth can explain the lack of population changes in low growth areas. I do this by using the FEMA relief payments data. Guidelines from the agency imply that lower income applicants for disaster relief will be given non-refundable payments as opposed to loans. A lower-wealth household will be able to pay lower amount out of pocket and therefore will likely be given a higher non-refundable payment for a given amount of damage. I test whether flood incidence among low-wealth households is higher in low growth communities by examining total FEMA payments per damage recorded and how they differ in low-growth communities. In particular I estimate:

$$
\ln \left(\text { FemaPay }_{i}=\beta \operatorname{Dam}_{i}+\gamma_{1} \operatorname{Dam}_{i} \times \operatorname{LSurp}_{i}+\gamma_{2} \operatorname{Dam}_{i} \times L G r_{i}+\alpha_{Y}+\{M u l F l\}+\epsilon_{i}\right.
$$


where FemaPay is total relief payments per capita, Dam is total damages recorded, and $\alpha_{Y}$ is a year effect. The specification estimates the fraction of damages disbursed by fema, $\beta$, and allows this to be different for low-surprise events, $\gamma_{1}$, and at low growth locations, $\gamma_{2}$. Positive $\gamma_{2}$ indicates that FEMA disburses more per given amount of damages in low growth locations, a result consistent with higher low-wealth incidence of flooding.

Results are shown in Table 5. The national cross-section, (1), reveals that low-growth locations do receive more non-refundable payments per recorded damage. When I estimate the same model allowing for regional heterogeneity we see that floods affect poorer communities in low growth areas mostly in Northeast and Mid/South Atlantic. Overall, there is evidence that at least in some parts of the US insufficient wealth can explain the lack of population change after flood surprises. It suggests that sorting will not necessarily occur in these parts. It still remains to be seen how real estate values respond in those regions as well.

Let us go back to the case of Milford vs the two neighbors. Figure 4 shows the evolution of population and real estate. Milford has a high history of flooding and the flood events do not constitute surprises. We see that population and real estate values (top tier) are not affected. New Haven and Bridgeport, on the other hand, see a decline in population but in line with the results in this section housing closely follows the trajectory of Milford and does not decline. This puts the two neighbors in the high-pre-growth group where demand for new housing seems to prevent a compensating decline that offsets higher risk. The cost increase is consistent with population decline.

\section{Regional Results}

The main results are based on a national sample which combines locations across various geographies each with specific climates and regulatory settings. The econometric specification accounts for this heterogeneity with the individual average, trend, and state-year effects but 
we cannot be certain that the identified responses are a general phenomenon occurring across the country. It is possible that population responds strongly only in one area of the US with there being no effect elsewhere. Additionally, I have also argued that real estate variations are closely related and help understand population effects. It is important to confirm that this relationship is maintained within separate regions. I investigate within-country heterogeneity by allowing the main coefficients to vary by a grouping based on a mix between Census divisions and regions - region 1 is split into Northeast and Mid-Atlantic; region 3 is split into South Atlantic and South Central.

The regional results for population are listed in Table 6 . The table includes coefficients from one estimation - different columns show estimates by surprise/pre-growth group. For example, the coefficients for the high-surprise/high-growth group from the Mid-Atlantic region is listed in the second column rows 2,8 , and 14 . The results confirm that surprises affect population at high pre-growth communities. Not all regions experience on impact, post, and trend break effects but all of them feature some combination. This suggests that the national results identify a general phenomenon where new movers choose a different destination after risk increases. Notice that the population decline at high pre-growth communities with low surprises estimated in the main results actually can be traced exclusively to the Northeast region and is not as general. This cautions against directly interpreting the national results without confirming that they hold at the regional level.

Regional real estate results for top-tier housing are shown in Table 7 . We see no real estate depreciation in any of the regions for high-surprise/high-growth locations. The only exception is the Northeast region which sees a trend break. This supports the interpretation of the population declines. The case of the South Atlantic is somewhat different. Highsurprise/high-growth areas do not experience population decline on impact - they see a trend break. This implies that population was not significantly affected and demand for new housing persisted. Uninterrupted population is reflected in the increase in house prices for this group. This suggests that expected flood risk may not have adjusted significantly after 
the flood surprises. Alternatively, it is likely that the high-surprise group includes locations where risk is already perceived to be high - consistent with the insurance estimates for South Atlantic in Table 2.

Housing depreciates in low pre-growth communities in all regions except for the Midwest and South Central. The price reduction paired with minimal changes in population in these locations is consistent with turnover in the local population where some sorting based on risk occurs. In the case of Midwest and South Central there are both minimal population changes and no price adjustment. Living in these areas effectively becomes more expensive but the real estate does not provide compensation. The evidence from the FEMA payments suggests that at least for the South Central area the incidence of the disaster may be higher on low-wealth households. This can explain why we do not observe any population effects these communities are locked in.

Overall, the regional results for housing and population are closely matched. They provide evidence for the interaction between revisions of perceived flood risk and existing demand for new housing which ultimately determine whether more people will inhabit risky locations.

\section{Robustness}

\section{Relative Damage vs Flood Indicator}

The results in this paper use an indicator for a flood based on a cutoff for minimum relative damage. I investigate the extent to which actual relative damage affects the main results regarding population. I introduce variations in damage by replacing the flood indicator with three indicators for relative damage. These indicators reflect the lower $33^{\text {th }} / 33^{\text {th }}-66^{\text {th }} /$ upper $66^{t h}$ percentile respectively of the distribution of damages at the state level. Specifying the main population model with them rather than a flood indicator allows us to examine whether events with relatively higher damage are different from those with relatively lower one. The 
results are shown in Table 8 . Focusing on the models with controls we can see that all parts of the damage distribution reduce population for the respective groups that are affected in the main results. The effect of the upper $66^{t h}$ percentile is slightly lower while the lower $33^{\text {th }}$ percentile generally has higher effects. These are not statistically different from each other.

\section{Local Social Organizations and Churches}

A big literature on resilience after natural disasters emphasizes the importance of local social capital (Aldrich 2012). To accommodate this I use information from the County Business Patterns dataset which lists the total number of establishments at a zip code by 6-digit industry code. I calculate the total number of civic and social organizations (NAICS 813410) and religious organizations (NAICS 813110) per capita in each community and define an indicator for locations with above state-median number. I then include it among the rest of the controls in $X_{i t}$. The results for population and real estate are listed in Table 9 . The coefficient estimates for the impact of higher level of social capital are listed at the bottom of the table. The overall results are very similar to the baseline. Social capital weakens the decline in the pre-flood trend for population and lowers the decline in the post period for the real estate values. These results are consistent with the literature on social capital which suggests that communities with higher endowment will do better after disasters.

\section{Conclusion}

This is the first study that investigates the effect of flood surprises using consistent national data of insured and uninsured damages at the level of the community. It investigates how changes in underlying flood risk affect the local population trajectory and real estate values. I find that changes in risk expectations are much more important that the amount of overall damage - at least in the case of lower scale events. Locations with a history of flooding do not experience changes in population and real estate. This indicates that flooding is widely 
expected and the local population is already somewhat insulated from the risk with insurance. Locations with flood surprises see a combination of declines in population and house value depreciation. The level of pre-existing demand for new housing is critical. Attractive communities that are surprised by a flood experience population declines and no housing depreciation, a combination consistent with new comers steering away. Less attractive locations see predominately house price declines and stable population. Using these results to interpret how climate change will affect communities within the US we will see three general local outcome. First, risky locations will not see any changes. Second, attractive locations where risk increases will experience population declines leading to stabilizing of population at the pre-flood level. Third, locations where risk increase and where demand for new housing is low will not see changes in population but will experience depreciation of housing. 


\section{Tables and Figures}

Table 1: Summary Statistics

\begin{tabular}{|c|c|c|c|c|c|c|c|c|c|c|}
\hline \multirow{2}{*}{\multicolumn{2}{|c|}{ Floods }} & \multirow{2}{*}{\multicolumn{2}{|c|}{ Percent }} & \multirow[b]{2}{*}{ Cum. } & & \multirow[b]{2}{*}{ State } & \multicolumn{4}{|c|}{ Number of Floods } \\
\hline & Freq. & & & & & & 0 & 1 & 2 & $3+$ \\
\hline 0 & 1,771 & \multicolumn{2}{|c|}{42.71} & \multicolumn{2}{|c|}{42.71} & Alabama & 41 & 50 & 5 & \\
\hline 1 & 1,519 & \multicolumn{2}{|c|}{36.63} & \multicolumn{2}{|c|}{79.33} & Arkansas & 20 & 40 & 17 & \\
\hline 2 & 542 & \multicolumn{2}{|c|}{13.07} & \multicolumn{2}{|c|}{92.4} & California & 316 & 45 & 1 & \\
\hline 3 & 238 & \multicolumn{2}{|c|}{5.74} & \multicolumn{2}{|c|}{98.14} & Colorado & 38 & 23 & & \\
\hline 4 & 77 & 1.8 & & 00 & & Connecticut & 36 & 33 & 7 & 5 \\
\hline Tot & 4,147 & 10 & & & & Delaware & 4 & 2 & & \\
\hline & & & & & & Florida & 7 & 99 & 34 & 47 \\
\hline & & Relat & ive Dam & age & & Georgia & 99 & 43 & 12 & 3 \\
\hline $\mathrm{Fl}$ & p25 & $\mathrm{p} 50$ & p75 & p90 & p95 & Illinois & 74 & 74 & 54 & 27 \\
\hline 1 & $0.02 \%$ & $0.05 \%$ & $0.14 \%$ & $0.46 \%$ & $0.87 \%$ & Indiana & 38 & 88 & 6 & 4 \\
\hline 2 & $0.02 \%$ & $0.06 \%$ & $0.19 \%$ & $0.69 \%$ & $1.55 \%$ & Iowa & 6 & 44 & 29 & \\
\hline 3 & $0.02 \%$ & $0.07 \%$ & $025 \%$ & $086 \%$ & $1.00 \%$ & Kentucky & 22 & 48 & 31 & 6 \\
\hline 4 & $0.00 \%$ & $0.09 \%$ & $0.24 \%$ & $127 \%$ & $\begin{array}{l}1.72 \% \\
866 \%\end{array}$ & Louisiana & 6 & 6 & 20 & 40 \\
\hline & & & & & & Maryland & 29 & 5 & & \\
\hline & & & & & & Massachusetts & 46 & 67 & 21 & 2 \\
\hline & & Total & Damage & & & Minnesota & 90 & 23 & 6 & 2 \\
\hline $\mathrm{Fl}$ & $\mathrm{p} 25$ & $\mathrm{p} 7$ & $\mathrm{p} 90$ & p95 & & Mississippi & 8 & 30 & 26 & 23 \\
\hline 1 & 0.64 & 5.0 & 16.1 & 42.39 & & Missouri & 38 & 48 & 30 & \\
\hline 2 & 0.64 & 5.7 & 20.7 & 47.18 & & Nevada & 13 & 2 & & \\
\hline 3 & 0.79 & 9.1 & 33.9 & 76.74 & & New Hampshire & 2 & 24 & & \\
\hline 4 & 0.83 & 13.5 & 69.6 & 213.8 & & New Jersey & 12 & 83 & 14 & 77 \\
\hline & & & & & & New York & 66 & 74 & 19 & 34 \\
\hline & Avera & age Pop & $(1,000)$ & & & North Carolina & 82 & 51 & 8 & 2 \\
\hline $\mathrm{Fl}$ & $\mathrm{p} 25 \mathrm{p} 50$ & $0 \quad \mathrm{p} 75$ & p90 I & 95 & & North Dakota & & 4 & 11 & \\
\hline 0 & 21 & 62 & 111 & 67 & & Ohio & 89 & 73 & 34 & 6 \\
\hline 1 & $\begin{array}{l}21 \\
21\end{array}$ & $\begin{array}{l}02 \\
57\end{array}$ & $\begin{array}{l}111 \\
110\end{array}$ & 79 & & Oklahoma & 25 & 38 & 15 & \\
\hline 2 & 22 & 55 & 104 & 07 & & Oregon & 45 & 10 & 2 & \\
\hline 3 & 21 & 60 & $\begin{array}{l}104 \\
139\end{array}$ & 14 & & Pennsylvania & 39 & 82 & 49 & 31 \\
\hline 4 & 23 & 77 & 139 & $\begin{array}{l}14 \\
84\end{array}$ & & Rhode Island & 2 & 12 & 14 & \\
\hline 4 & & & & & & South Carolina & 51 & 15 & & \\
\hline & & Popul & ation $\mathrm{G}$ & owth & & South Dakota & 7 & 7 & 1 & \\
\hline & & Popul & ation Gi & owth & & Tennessee & 38 & 75 & & \\
\hline $\mathrm{Fl}$ & p25 & & p75 & p90 & p95 & Texas & 170 & 65 & 56 & \\
\hline 0 & $-0.04 \%$ & $0.55 \%$ & $1.36 \%$ & $2.50 \%$ & $3.44 \%$ & Vermont & 3 & 13 & 2 & \\
\hline 1 & $-0.15 \%$ & $0.39 \%$ & $1.14 \%$ & $2.22 \%$ & $3.18 \%$ & Virginia & 67 & 28 & 6 & 4 \\
\hline 2 & $-0.24 \%$ & $0.28 \%$ & $0.97 \%$ & $1.97 \%$ & $2.90 \%$ & Washington & 64 & 26 & & \\
\hline 3 & $-0.27 \%$ & $0.21 \%$ & $0.75 \%$ & $1.71 \%$ & $2.51 \%$ & West Virginia & 20 & 23 & 5 & 2 \\
\hline 4 & $-0.20 \%$ & $0.31 \%$ & $0.96 \%$ & $2.20 \%$ & $3.12 \%$ & Wisconsin & 58 & 46 & 7 & \\
\hline & & & & & & Total & 1771 & 1519 & 542 & 315 \\
\hline
\end{tabular}


Table 2: Flood Surprises and Insurance Payouts

\begin{tabular}{|c|c|c|c|c|}
\hline VARIABLES & $\begin{array}{c}(1) \\
\ln (\text { Payouts })_{i}\end{array}$ & $\begin{array}{c}(2) \\
\ln (\text { Payouts })_{i}\end{array}$ & $\begin{array}{c}(3) \\
\ln (\text { Payouts })_{i}\end{array}$ & $\begin{array}{c}(4) \\
\ln (\text { Payouts })_{i}\end{array}$ \\
\hline $\mathrm{Hit}^{S F}$ & $\begin{array}{l}0.450^{*} \\
(0.230)\end{array}$ & & & \\
\hline $\mathrm{Hit}^{S F} \times$ LSurprise & $\begin{array}{c}0.963^{* * *} \\
(0.119)\end{array}$ & & & \\
\hline $\mathrm{Hit}^{S F} \times$ Northeast & & $\begin{array}{l}0.0442 \\
(0.588)\end{array}$ & & \\
\hline $\mathrm{Hit}^{S F} \times$ Mid-Atlantic & & $\begin{array}{c}0.706^{* * *} \\
(0.228)\end{array}$ & & \\
\hline $\mathrm{Hit}^{S F} \times$ Midwest & & $\begin{array}{r}-0.0915 \\
(0.216)\end{array}$ & & \\
\hline $\mathrm{Hit}^{S F} \times$ South Atlantic & & $\begin{array}{l}1.048^{* *} \\
(0.472)\end{array}$ & & \\
\hline $\mathrm{Hit}^{S F} \times$ South Central & & $\begin{array}{c}0.209 \\
(0.358)\end{array}$ & & \\
\hline $\mathrm{Hit}^{S F} \times$ West & & $\begin{array}{l}-0.438 \\
(0.307)\end{array}$ & & \\
\hline $\mathrm{Hit}^{S F} \times$ Northeast $\times$ LSurp & & $\begin{array}{c}1.338^{* * * *} \\
(0.145)\end{array}$ & & \\
\hline $\mathrm{Hit}^{S F} \times$ Mid-Atlantic $\times$ LSurp & & $\begin{array}{c}0.929^{* * *} \\
(0.150)\end{array}$ & & \\
\hline $\mathrm{Hit}^{S F} \times$ Mid West $\times$ LSurp & & $\begin{array}{c}1.265^{* * *} \\
(0.257)\end{array}$ & & \\
\hline $\mathrm{Hit}^{S F} \times$ South Atlantic $\times$ LowSurp & & $\begin{array}{l}0.624^{*} \\
(0.339)\end{array}$ & & \\
\hline $\mathrm{Hit}^{S F} \times$ South Central $\times$ LSurp & & $\begin{array}{c}0.796^{* * *} \\
(0.221)\end{array}$ & & \\
\hline $\mathrm{Hit}^{S F} \times$ West $\times$ LSurp & & $\begin{array}{c}1.668^{* * *} \\
(0.185)\end{array}$ & & \\
\hline $\mathrm{Hit}^{S F} \times \mathrm{Dam}$ & & & $\begin{array}{c}0.428^{* * *} \\
(0.0886)\end{array}$ & \\
\hline $\mathrm{Hit}^{S F} \times$ Dam $\times$ LSurprise & & & $\begin{array}{l}0.234^{* * *} \\
(0.0276)\end{array}$ & \\
\hline $\mathrm{Hit}^{S F} \times$ Dam $\times$ Northeast & & & & $\begin{array}{c}0.476^{* * *} \\
(0.148)\end{array}$ \\
\hline $\mathrm{Hit}^{S F} \times$ Dam $\times$ Mid-Atlantic & & & & $\begin{array}{l}0.640^{* * *} \\
(0.0508)\end{array}$ \\
\hline $\mathrm{Hit}^{S F} \times$ Dam $\times$ Midwest & & & & $\begin{array}{c}0.396^{* * *} \\
(0.0554)\end{array}$ \\
\hline $\mathrm{Hit}^{S F} \times$ Dam $\times$ South Atlantic & & & & $\begin{array}{c}0.355^{* * *} \\
(0.115)\end{array}$ \\
\hline $\mathrm{Hit}^{S F} \times$ Dam $\times$ South Central & & & & $\begin{array}{l}0.448^{* * *} \\
(0.0840)\end{array}$ \\
\hline $\mathrm{Hit}^{S F} \times$ Dam $\times$ West & & & & $\begin{array}{l}0.366^{* * *} \\
(0.0597)\end{array}$ \\
\hline $\mathrm{Hit}^{S F} \times$ Dam $\times$ Northeast $\times$ LSurp & & & & $\begin{array}{l}0.266^{* * *} \\
(0.0593)\end{array}$ \\
\hline $\mathrm{Hit}^{S F} \times$ Dam $\times$ Mid-Atlantic $\times$ LSurp & & & & $\begin{array}{l}0.153^{* * *} \\
(0.00957)\end{array}$ \\
\hline $\mathrm{Hit}^{S F} \times$ Dam $\times$ Mid West $\times$ LSurp & & & & $\begin{array}{c}0.298^{* * *} \\
(0.0227)\end{array}$ \\
\hline $\mathrm{Hit}^{S F} \times$ Dam $\times$ South Atlantic $\times$ LowSurp & & & & $\begin{array}{l}0.241^{* * *} * \\
(0.0428)\end{array}$ \\
\hline Hit $^{S F} \times$ Dam $\times$ South Central $\times$ LSurp & & & & $\begin{array}{c}0.171^{* * *} \\
(0.0594)\end{array}$ \\
\hline $\mathrm{Hit}^{S F} \times$ Dam $\times$ West $\times$ LSurp & & & & $\begin{array}{r}0.317^{* * *} \\
(0.0438)\end{array}$ \\
\hline Observations & 3,443 & 3,443 & 3,443 & 3,443 \\
\hline R-squared & 0.613 & 0.620 & 0.778 & 0.793 \\
\hline Additional Controls & Yes & Yes & Yes & Yes \\
\hline Year FE & Yes & Yes & Yes & Yes \\
\hline
\end{tabular}


Table 3: Flood Surprises and Population Changes

\begin{tabular}{|c|c|c|c|c|c|c|}
\hline VARIABLES & $\begin{array}{c}(1) \\
\ln P_{o p}\end{array}$ & $\begin{array}{c}(2) \\
\ln P_{o p}\end{array}$ & $\begin{array}{c}(3) \\
\ln \text { Pop }_{i t}\end{array}$ & $\begin{array}{c}(4) \\
\ln \text { Pop }_{i t}\end{array}$ & $\begin{array}{c}(5) \\
\ln \stackrel{P o p}{i t}\end{array}$ & $\begin{array}{c}(6) \\
\ln \stackrel{P o p}{i t}\end{array}$ \\
\hline $\mathrm{Hit}^{S F}$ & $\begin{array}{r}-0.000840 \\
(0.00113)\end{array}$ & $\begin{array}{c}-0.00918^{* * *} \\
(0.00203)\end{array}$ & & & & \\
\hline PostHit $^{S F}$ & & $\begin{array}{c}-0.00934^{* * *} \\
(0.00278)\end{array}$ & & & & \\
\hline PostTrend ${ }^{S F}$ & $\begin{array}{l}-4.08 \mathrm{e}-05 \\
(0.000484)\end{array}$ & $\begin{array}{c}-0.00404^{* * *} \\
(0.000855)\end{array}$ & & & & \\
\hline $\mathrm{Hit}^{S F} \times$ HSurp & & & $\begin{array}{c}-0.00310^{* *} \\
(0.00121)\end{array}$ & $\begin{array}{c}-0.0120^{* * *} \\
(0.00241)\end{array}$ & & \\
\hline $\mathrm{Hit}^{S F} \times \mathrm{LSurp}$ & & & $\begin{array}{c}0.00292 \\
(0.00193)\end{array}$ & $\begin{array}{c}-0.00487^{* *} \\
(0.00234)\end{array}$ & & \\
\hline PostHit $^{S F} \times$ HSurp & & & $\begin{array}{c}-0.00462^{* * *} \\
(0.00174)\end{array}$ & $\begin{array}{c}-0.0103^{* * *} \\
(0.00312)\end{array}$ & & \\
\hline PostHit $^{S F} \times$ LSurp & & & $\begin{array}{l}-0.00259 \\
(0.00217)\end{array}$ & $\begin{array}{c}-0.00758^{* *} \\
(0.00309)\end{array}$ & & \\
\hline PostTrend ${ }^{S F} \mathrm{~d} \times$ HSurp & & & $\begin{array}{l}-0.00148^{* *} \\
(0.000582)\end{array}$ & $\begin{array}{c}-0.00582^{* * *} \\
(0.000911)\end{array}$ & & \\
\hline PostTrend $^{S F} \times$ LSurp & & & $\begin{array}{l}0.00213^{* * *} \\
(0.000615)\end{array}$ & $\begin{array}{l}-0.00140 \\
(0.000931)\end{array}$ & & \\
\hline $\mathrm{Hit}^{S F} \times$ HSurp $\times$ LGr & & & & & $\begin{array}{c}0.00664^{* * *} \\
(0.00115)\end{array}$ & $\begin{array}{l}-0.00305 \\
(0.00243)\end{array}$ \\
\hline $\mathrm{Hit}^{S F} \times \operatorname{HSurp} \times \mathrm{HGr}$ & & & & & $\begin{array}{c}-0.00552^{* * *} \\
(0.00142)\end{array}$ & $\begin{array}{c}-0.0141^{* * *} \\
(0.00243)\end{array}$ \\
\hline $\mathrm{Hit}^{S F} \times$ LSurp $\times$ LGr & & & & & $\begin{array}{l}0.0118^{* *} \\
(0.00537)\end{array}$ & $\begin{array}{l}0.00347 \\
(0.00505)\end{array}$ \\
\hline $\mathrm{Hit}^{S F} \times \mathrm{LSurp} \times \mathrm{HGr}$ & & & & & $\begin{array}{l}0.000115 \\
(0.00132)\end{array}$ & $\begin{array}{c}-0.00752^{* * *} \\
(0.00210)\end{array}$ \\
\hline PostHit $^{S F} \times$ HSurp $\times$ LGr & & & & & $\begin{array}{l}0.000943 \\
(0.00190)\end{array}$ & $\begin{array}{l}-0.00530 \\
(0.00333)\end{array}$ \\
\hline PostHit $^{S F} \times$ HSurp $\times$ HGr & & & & & $\begin{array}{c}-0.00534^{* * *} \\
(0.00206)\end{array}$ & $\begin{array}{c}-0.0113^{* * *} \\
(0.00315)\end{array}$ \\
\hline PostHit $^{S F} \times$ LSurp $\times$ LGr & & & & & $\begin{array}{c}0.00253 \\
(0.00478)\end{array}$ & $\begin{array}{l}-0.00267 \\
(0.00474)\end{array}$ \\
\hline PostHit $^{S F} \times$ LSurp $\times$ HGr & & & & & $\begin{array}{l}-0.00329 \\
(0.00213)\end{array}$ & $\begin{array}{c}-0.00841^{* * * *} \\
(0.00318)\end{array}$ \\
\hline PostTrend $^{S F} \times$ HSurp $\times$ LGr & & & & & $\begin{array}{l}0.00695^{* * *} \\
(0.000597)\end{array}$ & $\begin{array}{l}0.00222^{* *} \\
(0.000894)\end{array}$ \\
\hline PostTrend $^{S F} \times \operatorname{HSurp} \times \mathrm{HGr}$ & & & & & $\begin{array}{c}-0.00410^{* * *} \\
(0.000655)\end{array}$ & $\begin{array}{c}-0.00788^{* * *} \\
(0.000917)\end{array}$ \\
\hline PostTrend $^{S F} \times$ LSurp $\times$ LGr & & & & & $\begin{array}{l}0.00891^{* * *} \\
(0.000874)\end{array}$ & $\begin{array}{c}0.00498^{* * *} \\
(0.00104)\end{array}$ \\
\hline PostTrend $^{S F} \times$ LSurp $\times \mathrm{HGr}$ & & & & & $\begin{array}{l}-0.000591 \\
(0.000693)\end{array}$ & $\begin{array}{c}-0.00381^{* * *} \\
(0.000967)\end{array}$ \\
\hline Observations & 70,403 & 70,403 & 70,403 & 70,403 & 70,403 & 70,403 \\
\hline Within R-squared & 0.005 & 0.023 & 0.009 & 0.028 & 0.039 & 0.052 \\
\hline$X_{i t}$ Controls & No & Yes & No & Yes & No & Yes \\
\hline \multicolumn{7}{|c|}{$\begin{array}{l}\text { Notes: }{ }^{* *} \mathrm{p}<0.01,{ }^{* *} \mathrm{p}<0.05,{ }^{*} \mathrm{p}<0.1 . \text { Hit } \\
\text { period following the first year of impact. PostTrend } \mathrm{d}^{S F} \text { is a linear trend starting the in the period following the } \\
\text { impact. LSurp/HSurp is an indicator for a low/high surprise event. LGr/HGr is an indicator for positive/negative } \\
\text { population growth } 5 \text { years prior to the event. Sample: } 2000 / 2016 \text {. SE clustered by community. Additional controls: } \\
\text { indicators for top } 66^{\text {th }} \text { perc. of fema/insured/business/sba damage; above median non-construction-based local } \\
\text { economy; above median renter fraction; below } 33^{\text {th }} \text { perc. tot. damage. The estimation results do not report the } \\
\text { coefficients for multiple-flood communities. }\end{array}$} \\
\hline
\end{tabular}


Table 4: Flood Surprises and Real Estate Values

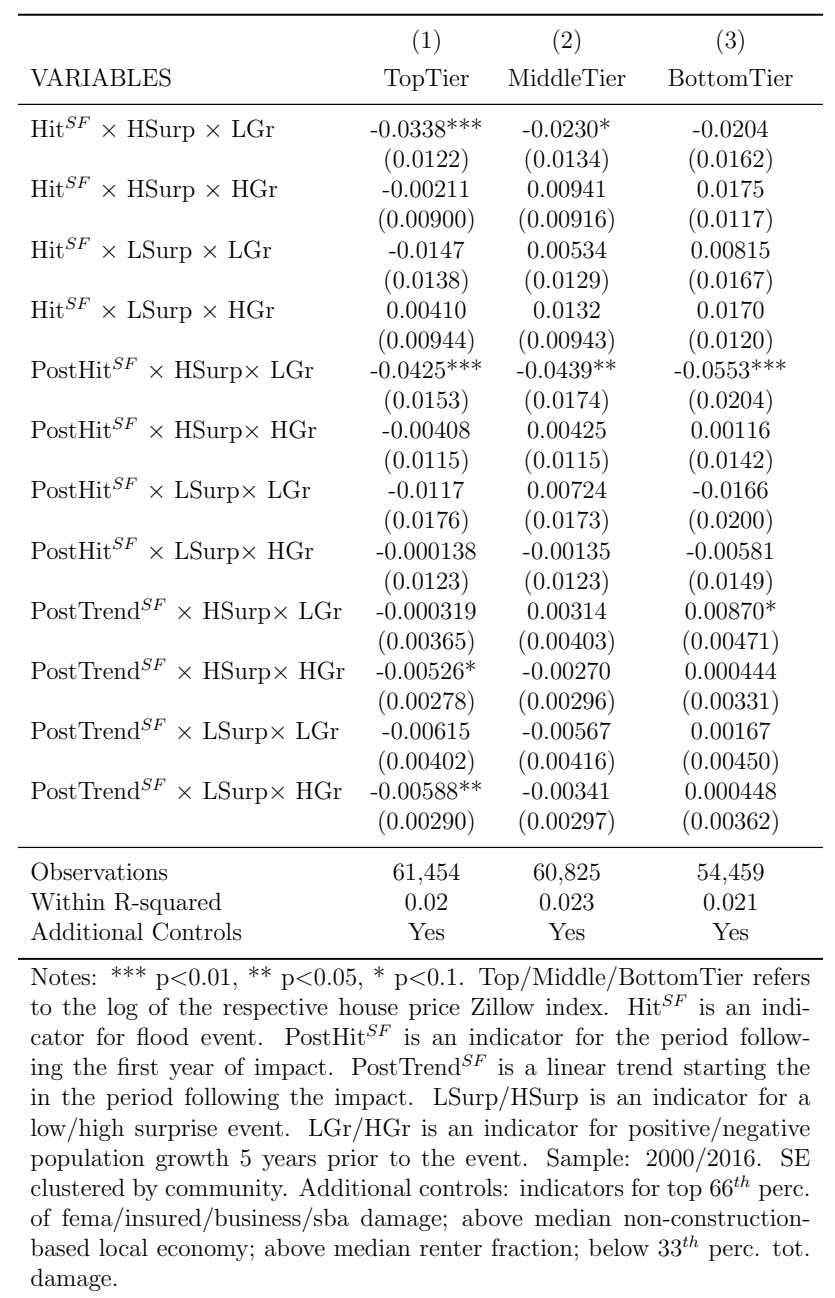


Table 5: Low-wealth Incidence in Low-Growth Communities

\begin{tabular}{|c|c|c|}
\hline VARIABLES & $\ln ($ FemaPay $)$ & $\ln ($ FemaPay $)$ \\
\hline $\mathrm{Hit}^{S F} \times \mathrm{Dam}$ & $\begin{array}{r}0.859^{* * *} \\
(0.0141)\end{array}$ & \\
\hline $\mathrm{Hit}^{S F} \times$ Dam $\times$ LSurp & $\begin{array}{l}-0.00489 \\
(0.00808)\end{array}$ & \\
\hline $\mathrm{Hit}^{S F} \times \mathrm{Dam} \times \mathrm{LGr}$ & $\begin{array}{c}0.0307^{* *} \\
(0.0143)\end{array}$ & \\
\hline $\mathrm{Hit}^{S F} \times$ Dam $\times$ Northeast & & $\begin{array}{c}0.923^{* * *} \\
(0.0285)\end{array}$ \\
\hline $\mathrm{Hit}^{S F} \times$ Dam $\times$ Mid-Atlantic & & $\begin{array}{c}0.816^{* * *} \\
(0.0188)\end{array}$ \\
\hline $\mathrm{Hit}^{S F} \times$ Dam $\times$ Midwest & & $\begin{array}{l}0.911^{* * *} \\
(0.0154)\end{array}$ \\
\hline $\mathrm{Hit}^{S F} \times$ Dam $\times$ South Atlantic & & $\begin{array}{l}0.816^{* * *} \\
(0.0162)\end{array}$ \\
\hline $\mathrm{Hit}^{S F} \times$ Dam $\times$ South Central & & $\begin{array}{l}0.881^{* * *} \\
(0.0102)\end{array}$ \\
\hline $\mathrm{Hit}^{S F} \times$ Dam $\times$ West & & $\begin{array}{l}0.821^{* * *} \\
(0.0247)\end{array}$ \\
\hline $\mathrm{Hit}^{S F} \times$ Dam $\times$ LSurp $\times$ Northeast & & $\begin{array}{l}-0.0435 \\
(0.0392)\end{array}$ \\
\hline $\mathrm{Hit}^{S F} \times$ Dam $\times$ LSurp $\times$ Mid-Atlantic & & $\begin{array}{c}0.0140 \\
(0.0244)\end{array}$ \\
\hline $\mathrm{Hit}^{S F} \times$ Dam $\times$ LSurp $\times$ Midwest & & $\begin{array}{l}-0.0116 \\
(0.0143)\end{array}$ \\
\hline $\mathrm{Hit}^{S F} \times$ Dam $\times$ LSurp $\times$ South Atlantic & & $\begin{array}{l}0.00162 \\
(0.0143)\end{array}$ \\
\hline $\mathrm{Hit}^{S F} \times$ Dam $\times$ LSurp $\times$ South Central & & $\begin{array}{l}-0.0158 \\
(0.0130)\end{array}$ \\
\hline $\mathrm{Hit}^{S F} \times$ Dam $\times$ LSurp $\times$ West & & $\begin{array}{l}-0.0159 \\
(0.0243)\end{array}$ \\
\hline $\mathrm{Hit}^{S F} \times$ Dam $\times$ LGr $\times$ Northeast & & $\begin{array}{l}0.0318^{* *} \\
(0.0124)\end{array}$ \\
\hline $\mathrm{Hit}^{S F} \times \operatorname{Dam} \times \mathrm{LGr} \times$ Mid-Atlantic & & $\begin{array}{l}0.0253^{* * *} \\
(0.00757)\end{array}$ \\
\hline $\mathrm{Hit}^{S F} \times$ Dam $\times$ LGr $\times$ Midwest & & $\begin{array}{l}0.00139 \\
(0.0190)\end{array}$ \\
\hline $\mathrm{Hit}^{S F} \times$ Dam $\times$ LGr $\times$ South Atlantic & & $\begin{array}{r}-0.00168 \\
(0.0267)\end{array}$ \\
\hline $\mathrm{Hit}^{S F} \times$ Dam $\times$ LGr $\times$ South Central & & $\begin{array}{l}0.0359^{*} \\
(0.0191)\end{array}$ \\
\hline $\mathrm{Hit}^{S F} \times \operatorname{Dam} \times \operatorname{LGr} \times$ West & & $\begin{array}{l}-0.109^{* *} \\
(0.0521)\end{array}$ \\
\hline Observations & 3,105 & 3,145 \\
\hline R-squared & 0.973 & 0.971 \\
\hline Additional Controls & Yes & Yes \\
\hline \multicolumn{3}{|c|}{$\begin{array}{l}\text { Notes: }{ }^{* *} \mathrm{p}<0.01,{ }^{* *} \mathrm{p}<0.05,{ }^{*} \mathrm{p}<0.1 \text {. FemaPay refers to total FEMA } \\
\text { relief per capita, Dam refers to total FEMA damage recorded, LSurp is } \\
\text { an indicator for low-surprise event, and LGr is an indicator for low pre- } \\
\text { growth location. Sample: } 2000 / 2016 \text {. SE clustered by state. Additional } \\
\text { controls: indicators for top } 66^{\text {th }} \text { perc. of fema/insured/business/sba dam- } \\
\text { age; above median non-construction-based local economy; above median } \\
\text { renter fraction; below } 33^{\text {th }} \text { perc. tot. damage. }\end{array}$} \\
\hline
\end{tabular}


Table 6: Regional Population Responses

\begin{tabular}{|c|c|c|c|c|}
\hline \multirow[b]{3}{*}{ VARIABLES } & \multicolumn{4}{|c|}{$\ln P o p_{i t}^{s t}$} \\
\hline & \multicolumn{2}{|c|}{ HighSurprise } & \multicolumn{2}{|c|}{ LowSurprise } \\
\hline & LowGrowth & HighGrowth & LowGrowth & HighGrowth \\
\hline $\mathrm{Hit}^{S F} \times$ Northeast & $\begin{array}{c}-0.00754^{* *} \\
(0.00303)\end{array}$ & $\begin{array}{c}-0.0101 * * * \\
(0.00286)\end{array}$ & $\begin{array}{l}-0.00669^{*} \\
(0.00396)\end{array}$ & $\begin{array}{c}-0.00998^{* * *} \\
(0.00273)\end{array}$ \\
\hline $\mathrm{Hit}^{S F} \times$ Mid-Atlantic & $\begin{array}{l}-0.00504 \\
(0.00540)\end{array}$ & $\begin{array}{c}-0.0163^{* * *} \\
(0.00488)\end{array}$ & $\begin{array}{c}0.00213 \\
(0.00376)\end{array}$ & $\begin{array}{c}-0.00901^{*} \\
(0.00463)\end{array}$ \\
\hline $\mathrm{Hit}^{S F} \times$ Midwest & $\begin{array}{c}0.00438 \\
(0.00355)\end{array}$ & $\begin{array}{c}-0.0137 * * * \\
(0.00381)\end{array}$ & $\begin{array}{c}-0.000326 \\
(0.00577)\end{array}$ & $\begin{array}{l}-0.00311 \\
(0.00295)\end{array}$ \\
\hline $\mathrm{Hit}^{S F} \times$ South Atlantic & $\begin{array}{l}0.000893 \\
(0.00687)\end{array}$ & $\begin{array}{l}-0.00667 \\
(0.00576)\end{array}$ & $\begin{array}{c}0.00518 \\
(0.00532)\end{array}$ & $\begin{array}{l}-0.00812 \\
(0.00507)\end{array}$ \\
\hline $\mathrm{Hit}^{S F} \times$ South Central & $\begin{array}{l}-0.00315 \\
(0.00668)\end{array}$ & $\begin{array}{c}-0.0141^{* *} \\
(0.00630)\end{array}$ & $\begin{array}{l}0.0184 \\
(0.0164)\end{array}$ & $\begin{array}{l}-0.00271 \\
(0.00611)\end{array}$ \\
\hline $\mathrm{Hit}^{S F} \times$ West & $\begin{array}{c}-5.64 \mathrm{e}-05 \\
(0.0104)\end{array}$ & $\begin{array}{c}-0.0189^{* * * *} \\
(0.00660)\end{array}$ & $\begin{array}{c}-0.00613 \\
(0.0123)\end{array}$ & $\begin{array}{l}-0.00849 \\
(0.00832)\end{array}$ \\
\hline PostHit $^{S F} \times$ Northeast & $\begin{array}{c}-0.0142^{* * *} \\
(0.00527)\end{array}$ & $\begin{array}{c}-0.0175^{* * *} \\
(0.00435)\end{array}$ & $\begin{array}{l}-0.0122^{*} \\
(0.00676)\end{array}$ & $\begin{array}{c}-0.0139^{* * *} \\
(0.00455)\end{array}$ \\
\hline PostHit $^{S F} \times$ Mid-Atlantic & $\begin{array}{l}-0.00925 \\
(0.00998)\end{array}$ & $\begin{array}{c}-0.0113 \\
(0.00786)\end{array}$ & $\begin{array}{l}-0.00333 \\
(0.00711)\end{array}$ & $\begin{array}{c}-0.0113 \\
(0.00765)\end{array}$ \\
\hline PostHit $^{S F} \times$ Midwest & $\begin{array}{c}0.000359 \\
(0.00434)\end{array}$ & $\begin{array}{c}-0.0134^{* * *} \\
(0.00450)\end{array}$ & $\begin{array}{l}-0.00254 \\
(0.00531)\end{array}$ & $\begin{array}{l}0.000863 \\
(0.00403)\end{array}$ \\
\hline PostHit $^{S F} \times$ South Atlantic & $\begin{array}{l}-0.00438 \\
(0.00908)\end{array}$ & $\begin{array}{l}-0.00197 \\
(0.00794)\end{array}$ & $\begin{array}{l}-0.00829 \\
(0.00793)\end{array}$ & $\begin{array}{c}-0.0164^{* *} \\
(0.00800)\end{array}$ \\
\hline PostHit $^{S F} \times$ South Central & $\begin{array}{l}-0.00242 \\
(0.00815)\end{array}$ & $\begin{array}{l}-0.00915 \\
(0.00802)\end{array}$ & $\begin{array}{c}0.0113 \\
(0.0143)\end{array}$ & $\begin{array}{c}0.00184 \\
(0.00999)\end{array}$ \\
\hline PostHit $^{S F} \times$ West & $\begin{array}{l}0.00316 \\
(0.0130)\end{array}$ & $\begin{array}{c}-0.0267^{* * * *} \\
(0.00820)\end{array}$ & $\begin{array}{l}-0.0112 \\
(0.0163)\end{array}$ & $\begin{array}{l}-0.0132 \\
(0.0105)\end{array}$ \\
\hline PostTrend $^{S F} \times$ Northeast & $\begin{array}{c}0.00171 \\
(0.00154)\end{array}$ & $\begin{array}{r}-0.000892 \\
(0.00147)\end{array}$ & $\begin{array}{c}0.00366 \\
(0.00230)\end{array}$ & $\begin{array}{c}-0.00297^{* *} \\
(0.00149)\end{array}$ \\
\hline PostTrend $^{S F} \times$ Mid-Atlantic & $\begin{array}{c}0.00374 \\
(0.00290)\end{array}$ & $\begin{array}{c}-0.00868^{* * *} \\
(0.00268)\end{array}$ & $\begin{array}{c}0.00531^{* *} \\
(0.00252)\end{array}$ & $\begin{array}{l}-0.00171 \\
(0.00256)\end{array}$ \\
\hline PostTrend $^{S F} \times$ Midwest & $\begin{array}{c}0.00396^{* * *} \\
(0.00117)\end{array}$ & $\begin{array}{c}-0.00714^{* * *} \\
(0.00157)\end{array}$ & $\begin{array}{c}0.00443^{* * *} \\
(0.00129)\end{array}$ & $\begin{array}{c}-0.00498^{* * *} \\
(0.00133)\end{array}$ \\
\hline PostTrend $^{S F} \times$ South Atlantic & $\begin{array}{l}0.000617 \\
(0.00293)\end{array}$ & $\begin{array}{c}-0.0112^{* * *} \\
(0.00249)\end{array}$ & $\begin{array}{c}0.00492^{*} \\
(0.00276)\end{array}$ & $\begin{array}{c}-0.00305 \\
(0.00250)\end{array}$ \\
\hline PostTrend $^{S F} \times$ South Central & $\begin{array}{c}0.00477^{* * *} \\
(0.00183)\end{array}$ & $\begin{array}{c}-0.00460^{* * *} \\
(0.00176)\end{array}$ & $\begin{array}{c}0.00850^{* * *} \\
(0.00277)\end{array}$ & $\begin{array}{r}-0.000660 \\
(0.00263)\end{array}$ \\
\hline PostTrend $^{S F} \times$ West & $\begin{array}{l}0.00638^{*} \\
(0.00362)\end{array}$ & $\begin{array}{c}-0.0106^{* * *} \\
(0.00306)\end{array}$ & $\begin{array}{c}0.00903^{* *} \\
(0.00446)\end{array}$ & $\begin{array}{c}-0.00701^{* *} \\
(0.00281)\end{array}$ \\
\hline
\end{tabular}

Notes: ${ }^{* * *} \mathrm{p}<0.01,{ }^{* *} \mathrm{p}<0.05,{ }^{*} \mathrm{p}<0.1$. Consult notes for Table 3 for details. Sample: 2000/2016. SE clustered by community. Additional controls: indicators for top $66^{\text {th }}$ perc.

of fema/insured/business/sba damage; above median non-construction-based local economy; above median renter fraction; below $33^{\text {th }}$ perc. tot. damage. 
Table 7: Regional Real Estate Responses for Top Tier Housing

\begin{tabular}{|c|c|c|c|c|}
\hline \multirow[b]{3}{*}{ VARIABLES } & \multicolumn{4}{|c|}{ TopTier House Index } \\
\hline & \multicolumn{2}{|c|}{ HighSurprise } & \multicolumn{2}{|c|}{ LowSurprise } \\
\hline & LowGrowth & HighGrowth & LowGrowth & HighGrowth \\
\hline $\mathrm{Hit}^{S F} \times$ Northeast & $\begin{array}{c}-0.0404^{* *} \\
(0.0191)\end{array}$ & $\begin{array}{c}-0.0296^{*} \\
(0.0153)\end{array}$ & $\begin{array}{l}-0.0280 \\
(0.0256)\end{array}$ & $\begin{array}{c}-0.0381^{* *} \\
(0.0151)\end{array}$ \\
\hline $\mathrm{Hit}^{S F} \times$ Mid-Atlantic & $\begin{array}{l}0.00921 \\
(0.0293)\end{array}$ & $\begin{array}{c}0.0203 \\
(0.0260)\end{array}$ & $\begin{array}{c}0.0108 \\
(0.0332)\end{array}$ & $\begin{array}{l}-0.00540 \\
(0.0253)\end{array}$ \\
\hline $\mathrm{Hit}^{S F} \times$ Midwest & $\begin{array}{l}-0.0196 \\
(0.0222)\end{array}$ & $\begin{array}{l}0.00228 \\
(0.0157)\end{array}$ & $\begin{array}{l}0.00589 \\
(0.0181)\end{array}$ & $\begin{array}{c}0.0163 \\
(0.0148)\end{array}$ \\
\hline $\mathrm{Hit}^{S F} \times$ South Atlantic & $\begin{array}{c}-0.0917^{* * *} \\
(0.0251)\end{array}$ & $\begin{array}{r}0.0378^{* *} \\
(0.0164)\end{array}$ & $\begin{array}{l}-0.0200 \\
(0.0308)\end{array}$ & $\begin{array}{c}0.0232 \\
(0.0175)\end{array}$ \\
\hline $\mathrm{Hit}^{S F} \times$ South Central & $\begin{array}{c}-0.00133 \\
(0.0228)\end{array}$ & $\begin{array}{l}0.00963 \\
(0.0193)\end{array}$ & $\begin{array}{c}0.0132 \\
(0.0245)\end{array}$ & $\begin{array}{r}0.0459^{* *} \\
(0.0218)\end{array}$ \\
\hline $\mathrm{Hit}^{S F} \times$ West & $\begin{array}{c}-0.159^{* * *} \\
(0.0300)\end{array}$ & $\begin{array}{r}-0.00704 \\
(0.0274)\end{array}$ & $\begin{array}{c}-0.120^{* * *} \\
(0.0299)\end{array}$ & $\begin{array}{l}-0.0419 \\
(0.0282)\end{array}$ \\
\hline PostHit $^{S F} \times$ Northeast & $\begin{array}{c}-0.0572^{* *} \\
(0.0268)\end{array}$ & $\begin{array}{c}-0.0373^{*} \\
(0.0221)\end{array}$ & $\begin{array}{l}-0.0356 \\
(0.0355)\end{array}$ & $\begin{array}{c}-0.0519 * * \\
(0.0220)\end{array}$ \\
\hline PostHit $^{S F} \times$ Mid-Atlantic & $\begin{array}{c}-0.0959^{* * *} \\
(0.0370)\end{array}$ & $\begin{array}{l}-0.0261 \\
(0.0333)\end{array}$ & $\begin{array}{l}-0.0492 \\
(0.0414)\end{array}$ & $\begin{array}{c}-0.0597^{*} \\
(0.0323)\end{array}$ \\
\hline PostHit $^{S F} \times$ Midwest & $\begin{array}{c}0.000684 \\
(0.0256)\end{array}$ & $\begin{array}{c}0.0177 \\
(0.0167)\end{array}$ & $\begin{array}{c}0.0161 \\
(0.0234)\end{array}$ & $\begin{array}{r}0.0361^{* *} \\
(0.0163)\end{array}$ \\
\hline PostHit $^{S F} \times$ South Atlantic & $\begin{array}{l}-0.0428 \\
(0.0395)\end{array}$ & $\begin{array}{l}0.0459^{*} \\
(0.0253)\end{array}$ & $\begin{array}{c}-0.000888 \\
(0.0372)\end{array}$ & $\begin{array}{c}0.0241 \\
(0.0295)\end{array}$ \\
\hline PostHit $^{S F} \times$ South Central & $\begin{array}{c}0.0134 \\
(0.0296)\end{array}$ & $\begin{array}{c}0.0173 \\
(0.0240)\end{array}$ & $\begin{array}{c}0.0339 \\
(0.0359)\end{array}$ & $\begin{array}{c}0.0424 \\
(0.0266)\end{array}$ \\
\hline PostHit $^{S F} \times$ West & $\begin{array}{c}-0.219^{* * *} \\
(0.0424)\end{array}$ & $\begin{array}{l}-0.0265 \\
(0.0330)\end{array}$ & $\begin{array}{l}-0.0863^{*} \\
(0.0501)\end{array}$ & $\begin{array}{c}-0.0806^{* *} \\
(0.0387)\end{array}$ \\
\hline PostTrend $^{S F} \times$ Northeast & $\begin{array}{l}-0.0154^{* *} \\
(0.00642)\end{array}$ & $\begin{array}{r}-0.0126^{* *} \\
(0.00568)\end{array}$ & $\begin{array}{l}-0.00827 \\
(0.00969)\end{array}$ & $\begin{array}{l}-0.00917 \\
(0.00604)\end{array}$ \\
\hline PostTrend $^{S F} \times$ Mid-Atlantic & $\begin{array}{c}0.0287^{* * *} \\
(0.00967)\end{array}$ & $\begin{array}{c}0.00497 \\
(0.00966)\end{array}$ & $\begin{array}{l}0.0218^{* *} \\
(0.00913)\end{array}$ & $\begin{array}{c}0.0128 \\
(0.00814)\end{array}$ \\
\hline PostTrend $^{S F} \times$ Midwest & $\begin{array}{l}-0.00199 \\
(0.00522)\end{array}$ & $\begin{array}{l}-0.00443 \\
(0.00420)\end{array}$ & $\begin{array}{l}-0.00780 \\
(0.00493)\end{array}$ & $\begin{array}{l}-0.00386 \\
(0.00430)\end{array}$ \\
\hline PostTrend $^{S F} \times$ South Atlantic & $\begin{array}{c}-0.0280^{* * *} \\
(0.0101)\end{array}$ & $\begin{array}{l}-0.00343 \\
(0.00815)\end{array}$ & $\begin{array}{c}-0.0201^{*} \\
(0.0117)\end{array}$ & $\begin{array}{l}-0.0182^{* *} \\
(0.00780)\end{array}$ \\
\hline PostTrend $^{S F} \times$ South Central & $\begin{array}{c}0.00462 \\
(0.00758)\end{array}$ & $\begin{array}{l}-0.00172 \\
(0.00576)\end{array}$ & $\begin{array}{l}-0.00222 \\
(0.00760)\end{array}$ & $\begin{array}{c}0.00628 \\
(0.00599)\end{array}$ \\
\hline PostTrend $^{S F} \times$ West & $\begin{array}{l}-0.00554 \\
(0.0107)\end{array}$ & $\begin{array}{l}-0.00358 \\
(0.00710)\end{array}$ & $\begin{array}{l}0.00233 \\
(0.0266)\end{array}$ & $\begin{array}{c}-0.0103 \\
(0.00821)\end{array}$ \\
\hline
\end{tabular}


Table 8: Population Responses with Spline Damage Specification

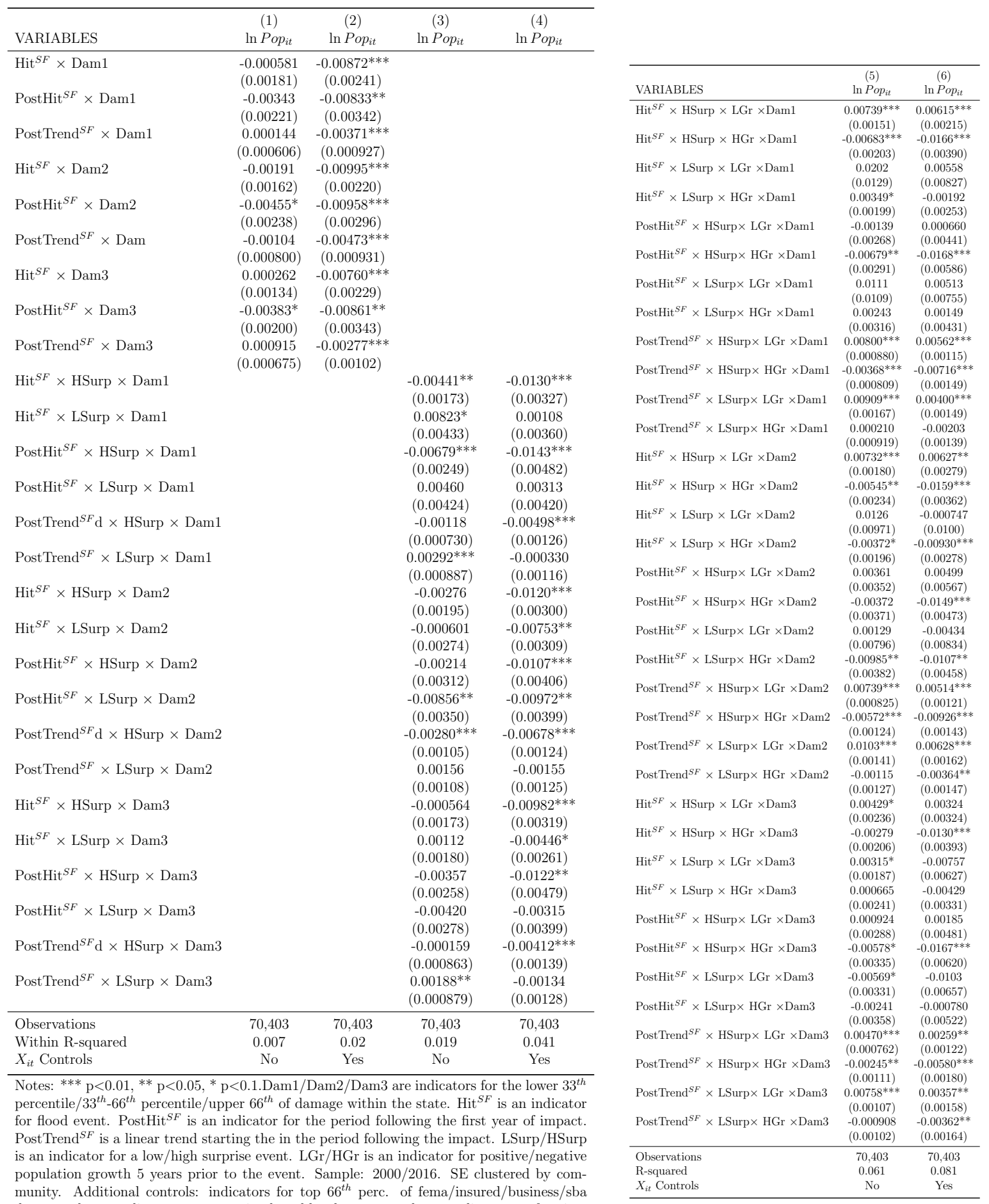


Table 9: Population and Real Estate Responses Controlling for Local Churches and Social Organizations

\begin{tabular}{|c|c|c|c|c|c|c|}
\hline VARIABLES & $\begin{array}{c}(1) \\
\ln \operatorname{Pop}_{i t}\end{array}$ & $\begin{array}{c}(2) \\
\ln P_{o p} i t\end{array}$ & $\begin{array}{c}(3) \\
\ln P_{o p} i t\end{array}$ & $\begin{array}{c}(4) \\
\text { TopTier }\end{array}$ & $\begin{array}{c}(5) \\
\text { MiddleTier }\end{array}$ & $\begin{array}{c}(6) \\
\text { BottomTier }\end{array}$ \\
\hline $\mathrm{Hit}^{S F}$ & $\begin{array}{c}-0.0101 * * * \\
(0.00230)\end{array}$ & & & & & \\
\hline PostHit $^{S F}$ & $\begin{array}{c}-0.00948^{* * *} \\
(0.00318)\end{array}$ & & & & & \\
\hline PostTrend $^{S F}$ & $\begin{array}{c}-0.00545^{* * *} \\
(0.000970)\end{array}$ & & & & & \\
\hline $\mathrm{Hit}^{S F} \times$ HSurp & & $\begin{array}{c}-0.0128^{* * *} \\
(0.00244)\end{array}$ & & & & \\
\hline $\mathrm{Hit}^{S F} \times$ LSurp & & $\begin{array}{c}-0.00577^{* *} \\
(0.00287)\end{array}$ & & & & \\
\hline PostHit $^{S F} \times$ HSurp & & $\begin{array}{c}-0.0103^{* * *} \\
(0.00336)\end{array}$ & & & & \\
\hline PostHit $^{S F} \times$ LSurp & & $\begin{array}{c}-0.00772^{* *} \\
(0.00362)\end{array}$ & & & & \\
\hline PostTrend $^{S F} \mathrm{~d} \times$ HSurp & & $\begin{array}{c}-0.00723^{* * *} \\
(0.00101)\end{array}$ & & & & \\
\hline PostTrend $^{S F} \times$ LSurp & & $\begin{array}{c}-0.00281^{* * *} \\
(0.00104)\end{array}$ & & & & \\
\hline $\mathrm{Hit}^{S F} \times$ HSurp $\times$ LGr & & & $\begin{array}{l}-0.00325 \\
(0.00244)\end{array}$ & $\begin{array}{c}-0.0369^{* * *} \\
(0.0125)\end{array}$ & $\begin{array}{r}-0.0261^{*} \\
(0.0135)\end{array}$ & $\begin{array}{l}-0.0275^{*} \\
(0.0160)\end{array}$ \\
\hline $\mathrm{Hit}^{S F} \times \mathrm{HSurp} \times \mathrm{HGr}$ & & & $\begin{array}{c}-0.0141^{* * *} \\
(0.00246)\end{array}$ & $\begin{array}{l}-0.00445 \\
(0.00917)\end{array}$ & $\begin{array}{c}0.00703 \\
(0.00930)\end{array}$ & $\begin{array}{c}0.0122 \\
(0.0118)\end{array}$ \\
\hline $\mathrm{Hit}^{S F} \times$ LSurp $\times$ LGr & & & $\begin{array}{c}0.00341 \\
(0.00603)\end{array}$ & $\begin{array}{l}-0.0183 \\
(0.0143)\end{array}$ & $\begin{array}{l}0.00181 \\
(0.0133)\end{array}$ & $\begin{array}{r}0.000337 \\
(0.0169)\end{array}$ \\
\hline $\mathrm{Hit}^{S F} \times \mathrm{LSurp} \times \mathrm{HGr}$ & & & $\begin{array}{c}-0.00758 * * * \\
(0.00234)\end{array}$ & $\begin{array}{c}0.00145 \\
(0.00961)\end{array}$ & $\begin{array}{c}0.0107 \\
(0.00966)\end{array}$ & $\begin{array}{c}0.0114 \\
(0.0120)\end{array}$ \\
\hline PostHit $^{S F} \times$ HSurp $\times$ LGr & & & $\begin{array}{l}-0.00501 \\
(0.00356)\end{array}$ & $\begin{array}{c}-0.0545^{* * *} \\
(0.0158)\end{array}$ & $\begin{array}{c}-0.0569^{* * *} \\
(0.0177)\end{array}$ & $\begin{array}{c}-0.0694^{* * *} \\
(0.0207)\end{array}$ \\
\hline PostHit $^{S F} \times$ HSurp $\times$ HGr & & & $\begin{array}{c}-0.0108^{* * *} \\
(0.00336)\end{array}$ & $\begin{array}{l}-0.0127 \\
(0.0118)\end{array}$ & $\begin{array}{r}-0.00556 \\
(0.0117)\end{array}$ & $\begin{array}{r}-0.00958 \\
(0.0144)\end{array}$ \\
\hline PostHit $^{S F} \times$ LSurp $\times$ LGr & & & $\begin{array}{l}-0.00213 \\
(0.00561)\end{array}$ & $\begin{array}{l}-0.0249 \\
(0.0183)\end{array}$ & $\begin{array}{c}-0.00689 \\
(0.0177)\end{array}$ & $\begin{array}{l}-0.0321 \\
(0.0205)\end{array}$ \\
\hline PostHit $^{S F} \times$ LSurp $\times$ HGr & & & $\begin{array}{c}-0.00808^{* *} \\
(0.00348)\end{array}$ & $\begin{array}{l}-0.00908 \\
(0.0125)\end{array}$ & $\begin{array}{l}-0.0110 \\
(0.0125)\end{array}$ & $\begin{array}{l}-0.0167 \\
(0.0154)\end{array}$ \\
\hline PostTrend $^{S F} \times$ HSurp $\times$ LGr & & & $\begin{array}{c}0.00124 \\
(0.00104)\end{array}$ & $\begin{array}{c}0.00144 \\
(0.00379)\end{array}$ & $\begin{array}{c}0.00518 \\
(0.00422)\end{array}$ & $\begin{array}{l}0.00855^{*} \\
(0.00500)\end{array}$ \\
\hline PostTrend $^{S F} \times$ HSurp $\times$ HGr & & & $\begin{array}{c}-0.00858^{* * *} \\
(0.00100)\end{array}$ & $\begin{array}{l}-0.00398 \\
(0.00281)\end{array}$ & $\begin{array}{l}-0.00118 \\
(0.00299)\end{array}$ & $\begin{array}{l}0.000514 \\
(0.00339)\end{array}$ \\
\hline PostTrend $^{S F} \times$ LSurp $\times$ LGr & & & $\begin{array}{c}0.00400^{* * *} \\
(0.00120)\end{array}$ & $\begin{array}{l}-0.00438 \\
(0.00414)\end{array}$ & $\begin{array}{l}-0.00366 \\
(0.00427)\end{array}$ & $\begin{array}{c}0.00149 \\
(0.00464)\end{array}$ \\
\hline PostTrend $^{S F} \times$ LSurp $\times$ HGr & & & $\begin{array}{c}-0.00448^{* * *} \\
(0.00105)\end{array}$ & $\begin{array}{l}-0.00474 \\
(0.00292)\end{array}$ & $\begin{array}{l}-0.00207 \\
(0.00299)\end{array}$ & $\begin{array}{l}0.000298 \\
(0.00369)\end{array}$ \\
\hline $\mathrm{Hit}^{S F} \times$ Social & $\begin{array}{c}0.00222 \\
(0.00194)\end{array}$ & $\begin{array}{c}0.00208 \\
(0.00194)\end{array}$ & $\begin{array}{l}0.000223 \\
(0.00210)\end{array}$ & $\begin{array}{c}0.00560 \\
(0.00581)\end{array}$ & $\begin{array}{c}0.00552 \\
(0.00606)\end{array}$ & $\begin{array}{c}0.0137^{*} \\
(0.00729)\end{array}$ \\
\hline PostHit $^{S F} \times$ Social & $\begin{array}{c}0.00109 \\
(0.00256)\end{array}$ & $\begin{array}{l}0.000896 \\
(0.00255)\end{array}$ & $\begin{array}{r}-0.000535 \\
(0.00258)\end{array}$ & $\begin{array}{c}0.0204^{* * *} \\
(0.00753)\end{array}$ & $\begin{array}{c}0.0228^{* * *} \\
(0.00790)\end{array}$ & $\begin{array}{c}0.0271^{* * * *} \\
(0.00959)\end{array}$ \\
\hline PostTrend $^{S F} \times$ Social & $\begin{array}{c}0.00284^{* * *} \\
(0.000711)\end{array}$ & $\begin{array}{c}0.00284^{* * *} \\
(0.000705)\end{array}$ & $\begin{array}{l}0.00150^{* *} \\
(0.000680)\end{array}$ & $\begin{array}{l}-0.00265 \\
(0.00184)\end{array}$ & $\begin{array}{l}-0.00318 \\
(0.00201)\end{array}$ & $\begin{array}{l}0.000614 \\
(0.00230)\end{array}$ \\
\hline Observations & 70,403 & 70,403 & 70,403 & 61,530 & 60,920 & 54,554 \\
\hline Within R-squared & 0.025 & 0.03 & 0.052 & 0.023 & 0.026 & 0.025 \\
\hline$X_{i t}$ Controls & Yes & Yes & Yes & Yes & Yes & Yes \\
\hline \multicolumn{7}{|c|}{$\begin{array}{l}\text { Notes: } * * * \mathrm{p}<0.01,{ }^{* *} \mathrm{p}<0.05,{ }^{*} \mathrm{p}<0.1 . \mathrm{Hit} S F \text { is an indicator for flood event. PostHit }{ }^{S F} \text { is an indicator } \\
\text { for the period following the first year of impact. PostTrend }{ }^{S F} \text { is a linear trend starting the in the period } \\
\text { following the impact. LSurp/HSurp is an indicator for a low/high surprise event. LGr/HGr is an indicator for } \\
\text { positive/negative population growth } 5 \text { years prior to the event. Social is an indicator for above median number } \\
\text { of social organizations and churches per capita. Sample: } 2000 / 2016 \text {. SE clustered by community. Additional } \\
\text { controls: indicators for top } 66^{t h} \text { perc. of fema/insured/business/sba damage; above median non-construction- } \\
\text { based local economy; above median renter fraction; below } 33^{\text {th }} \text { perc. tot. damage. The estimation results do } \\
\text { not report the coefficients for multiple-flood communities. }\end{array}$} \\
\hline
\end{tabular}




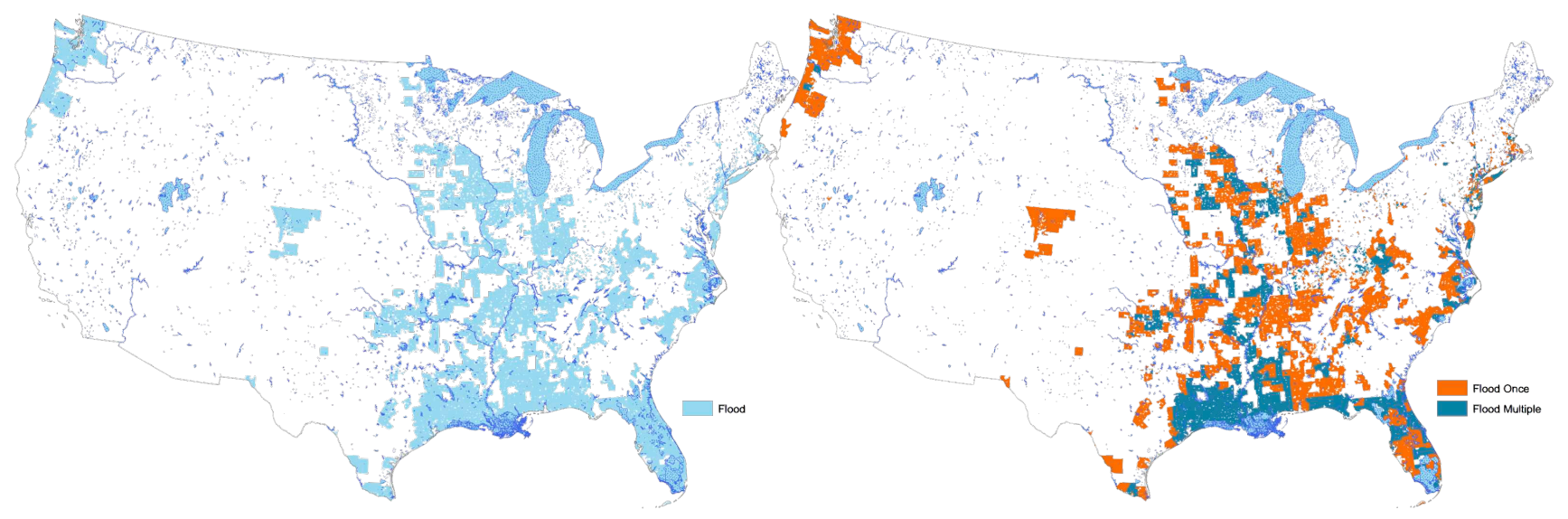

Figure 1: Locations with Single and Multiple Floods between 2003-2013

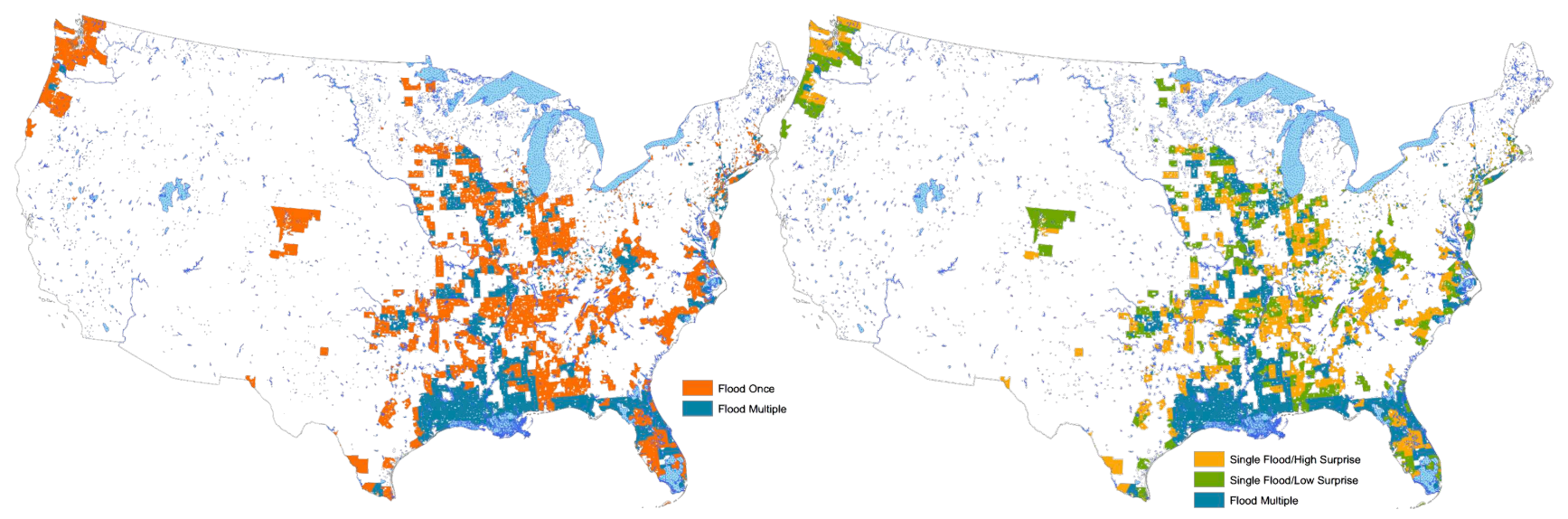

Figure 2: Locations with Flood Surprises between 2003-2013 


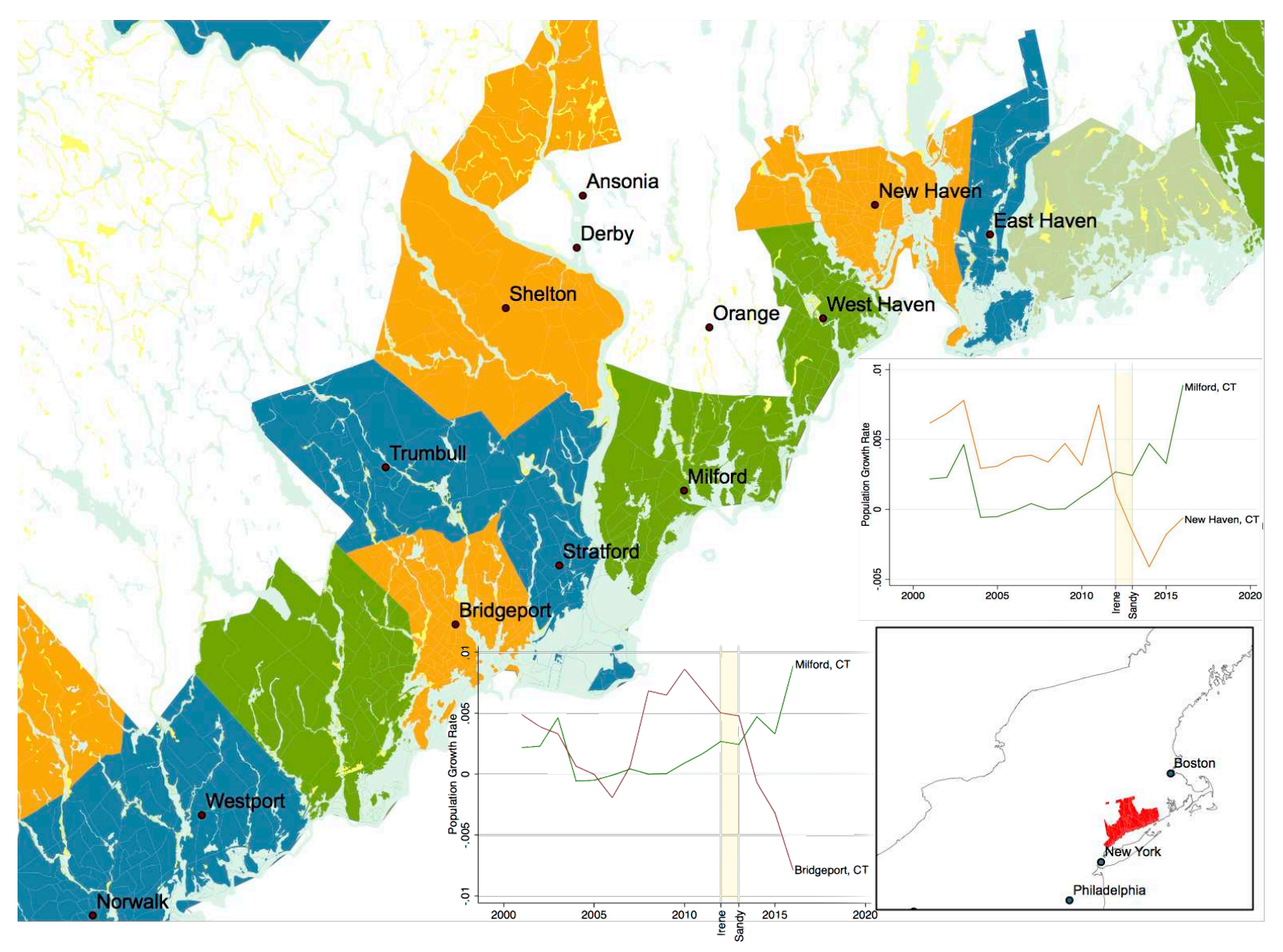

Figure 3: Population Growth of Milford vs New Haven and Bridgeport

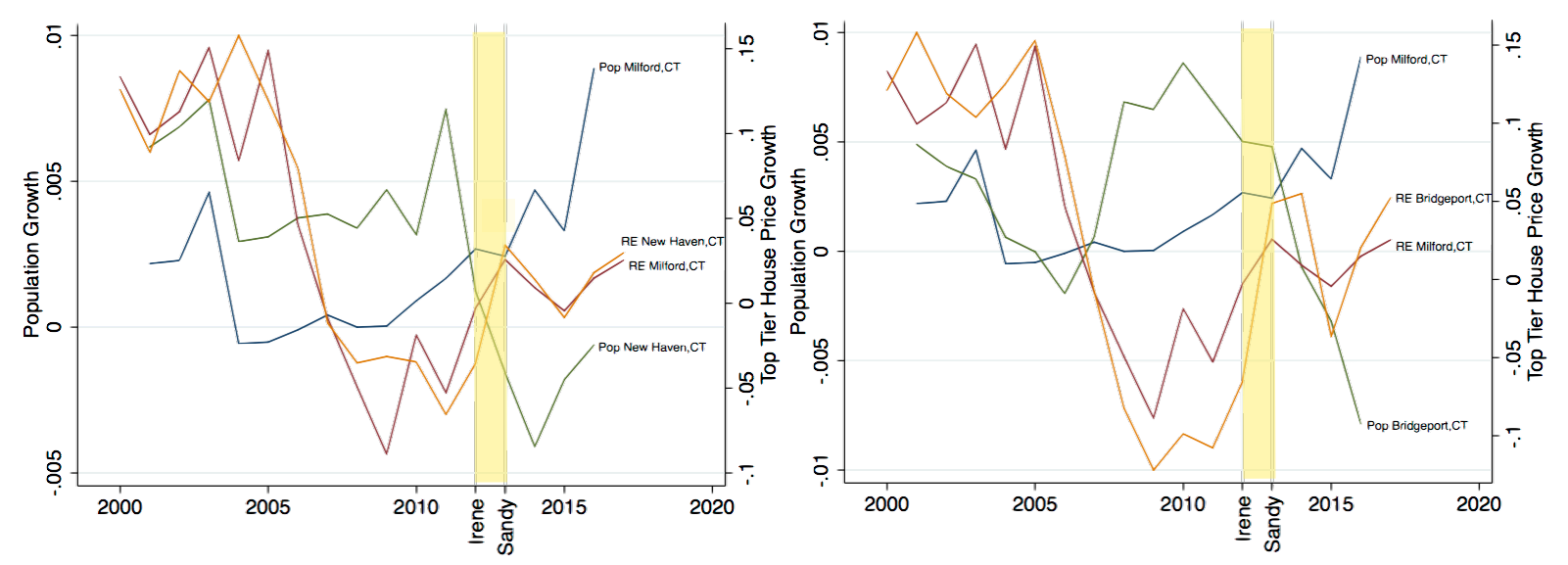

Figure 4: Population and Real Estate Values at Milford vs New Haven and Bridgeport 


\section{References}

[1] Aldrich, D. P. (2012). Building resilience: Social capital in post-disaster recovery. University of Chicago Press.

[2] Davis, L. W. (2004). "The Effect of Health Risk on Housing Values: Evidence from a Cancer Cluster." American Economic Review, 94(5), 1693-1704.

[3] Deryugina, T. (2017). "The Fiscal Cost of Hurricanes: Disaster Aid versus Social Insurance." American Economic Journal: Economic Policy, 9(3), 168-98.

[4] Diamond, R. (2016). "The Determinants and Welfare Implications of US Workers' Diverging Location Choices by Skill: 1980-2000." American Economic Review, 106(3), 479-524.

[5] Gallagher, J. (2014). "Learning about an Infrequent Event: Evidence from Flood Insurance Take-up in the United States". American Economic Journal: Applied Economics, 6(3), 206-33.

[6] Glaeser, E. L., and Gottlieb, J. D. (2009). "The Dealth of Cities: Agglomeration Economies and Spatial Equilibrium in the United States." Journal of Economic Literature, 47(4), 983-1028.

[7] Glaeser, E. L., and Gyourko, J. (2005). "Urban Decline and Durable Housing." Journal of Political Economy, 113(2), 345-375.

[8] Jaffe, J. (2015) Disaster Dollars: Financial Preparation and Recovery for Towns, Businesses, Farms, and Individuals. Lulu Publishing Services

[9] Moretti, E. (2011). "Local Labor Markets." Handbook of Labor Economics (Vol. 4, pp. 1237-1313). Elsevier.

[10] Stein, J, "Prices and Trading Volume in the Housing market: A Model with Down payment Effects," Quarterly Journal of Economics 110 (May 1995), 379-406.

[11] Strobl, E. (2011). "The Economic Growth Impact of Hurricanes: Evidence from US Coastal Counties." Review of Economics and Statistics, 93(2), 575-589.

[12] Topel, R. H. (1986). "Local Labor Markets". Journal of Political economy, 94(3, Part 2), S111-S143. 
Appendix (for online publication only) 